\title{
Evaluation of efficiency of general hospitals in Iran
}

\author{
Ali Mohammad Mosadeghrad ${ }^{1}$, Ghasem Janbabai ${ }^{2}$, Behzad Kalantari ${ }^{3}$, Mahya Abbasi ${ }^{4}$, Hamed Dehnavi $^{*}$ \\ 1. Associate Professor of Health Policy and Management, Department of Health Management and Economics, School of \\ Public Health, Health Information Management Research Center, Tehran University of Medical Sciences, Tehran, Iran. \\ ORCID CD: 0000-0002-7955-6292 \\ 2. Associate Professor, Department of Oncology and Hematology, Tehran University of Medical Sciences, Tehran, Iran. \\ ORCID CD: 0000-0003-2651-6200 \\ 3. MD-MBA-MPH, Department of Hospital management and organizational excellence, Ministry of Health and Medical \\ Education, Tehran, Iran. ORCID CD: 0000-0003-0069-2783 \\ 4. Ph.D Student in Health Care Management, Department of Health Management and Economics, School of Public Health, \\ Tehran University of Medical Sciences, Tehran, Iran. ORCID CD: 0000-0001-6372-9948 \\ 5. Ph.D Student in Health Care Management, Department of Health Management and Economics,School of Public Health, \\ Tehran University of Medical Sciences, Tehran, Iran, (Corresponding Author), Tel: 021-42933006, Email: \\ hamedehnavi@gmail.com. ORCID CD: 0000-0002-8183-4458
}

\begin{abstract}
Background and aim: Approximately $85 \%$ of Iranian hospitals are general hospitals. Considering the limitation of resourses, improvement of the hospital efficiency is an absolute necessity. Efficiency, as the output-input ratio, indicates use of the lowest amount of inputs to produce the greatest amount of outputs. The aim of this study was to determine the efficiency of general hospitals in Iran and identification of the factors affecting efficiency of the hospitals.

Materials and Methods: In this cross sectional and descriptive study we used Pabon Lasso model and three performance indicators. i.e., bed occupancy rate (BO), average length of stay (ALS) and hospital bed turnover (BT) to determine efficiency of the Iranian general hospitals in 2017. Data were analyzed by SPSS software and charts were drawn using Power BI software.

Results: There were 834 general hospitals with 108257 beds in Iran in 2017. The average BO, ALS and BT were $62.8 \%, 2.6$ days and 93 times respectively. Only $15 \%$ of the general hospitals were located in the zone III of pabon lasso model and had acceptable efficiency (high BO and BT). Factors such as hospital ownership, type, size, age of hospital building, and staff number were significantly related to hospital efficiency. Private and social security hospitals, non- teaching hospitals and hospitals with 100-200 beds and 2-4 staff per bed had more efficiency in comparison to the teaching hospitals.
\end{abstract}

Conclusion: Because of low efficiency of most general hospitals policy makers and senior managers should take necessary measures for improvement of efficiency of the hospitals.

Keywords: General hospital, Efficiency, Pabon Lasso, Cross- sectional studies, Iran

Received: Feb 24, 2020

Accepted: Oct 3, 2020

How to cite the article: Ali Mohammad Mosadeghrad, Ghasem Janbabai, Behzad Kalantari, Mahya Abbasi, Hamed Dehnavi. Evaluation of efficiency of general hospitals in Iran SJKU. 2021;26(3):151-I 169.

Copyright ( 2018 the Author (s). Published by Kurdistan University of Medical Sciences. This is an open access article distributed under the terms of the Creative Commons Attribution-Non-Commercial License 4.0 (CCBYNC), where it is permissible to download, share, remix, transform, and buildup the work provided it is properly cited. The work cannot be used commercially without permission from the journal 


\section{ارزشيابى كارايى بيمارستانهاى عمومى ايران}

على محمد مصدقراد'، قاسم جانبابيى"، بهزاد كلانترى"، محيا عباسىء، حامد دهنوىْ

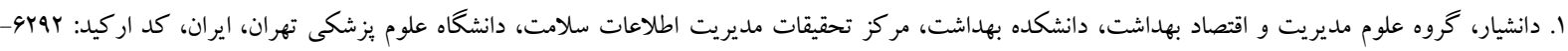

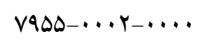

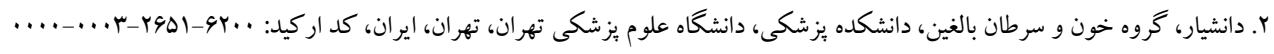

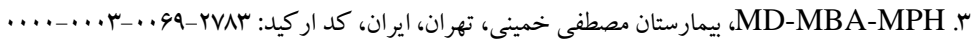

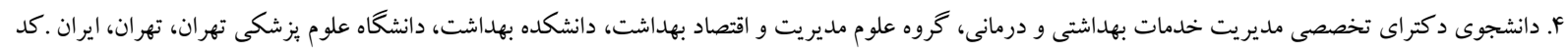
ار كيد:

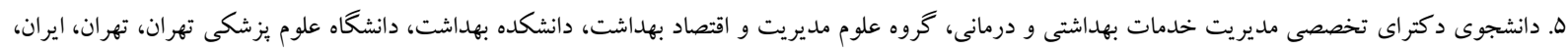

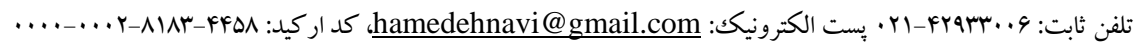
جكکبه زمينه و هدف: بيمارستانهاى عمومى بيش از هم درصد بيمارستانهاى كشور را تشكيل مىدهند. افزايش كارايى بيمارستانهاى عمومى با توجه به محدوديت منابع ضرورى است. كارايى نسبت ستادهها به دادهها بوده و بيانگر توليد حداكثر ستاده با استفاده از دادههاى معين است. مطالعه حاضر با هدف ارزشيابى كارايى بيمارستانهاى عمومى كشور و شناسايى عوامل موثر بر كارايى آنها انجام شد.

روش بروسى: اين مطالعه توصيفى - تحليلى به صورت مقطعى انجام شده است. از نمودار بابنلاسو و سه شاخص عملكردى درصد اشغال تخت، متوسط اقامت بيماران و ميزان گردش تخت بيمارستان براى تعيين كارايى بيمارستانهاى عمومى كشور استفاده شد. از دادهاى عملكردى سال وهسا بيمارستانهاى عمومى كشور استفاده شد. دادهها با استفاده از نرمافزار SPSS تحليل و نمودارها با كمكك نرمافزار Power BI ترسيم شدند.

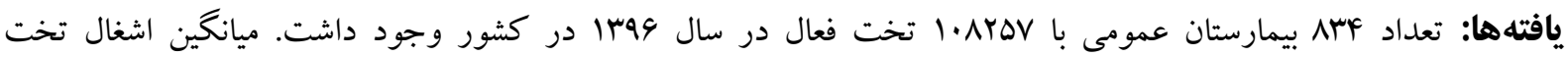

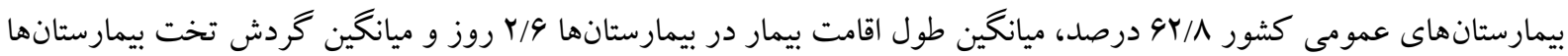
سو بار بود. حدود ها درصد بيمارستانها در ناحيه سوم نمودار پيابنلاسو قرار گرفته و كارايى قابل قبولى داشتند. بين كارايى بيمارستان و مالكيت، مأموريت، اندازه، قدمت و تعداد كار كنان بيمارستان رابطه آمارى معنادارى مشاهده شد. بيمارستانهاى تأمين اجتماعى و خصوصى از كارايى بيشترى برخوردار بودند. بيمارستانهاى درمانى كارايى بيشترى نسبت به بيمارستانهاى آموزشى، درمانى و ئزوهشى داشتند. بيشترين ميزان كارايى در بيمارستانهاى با . .Y-... تخت و F-Y كارمند به ازاى هر تخت مشاهده شد. نتيجه كيرى: بيمارستانهاى عمومى كشور از كارايى بايينى برخوردار هستند. بنابراين، سياستخذاران و مديران ارشد نظام سلامت ايران بايد اقدامات لازم رابراى افزايش كارايى و استفاده بهينه از منابع موجود بكار كيرند. كلمات كليدى: بيمارستان عمومى، كارايى، يابن لاسو، مطالعات مقطعى، ايران

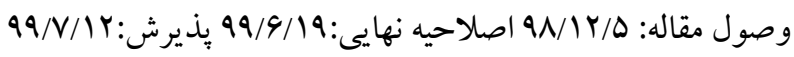




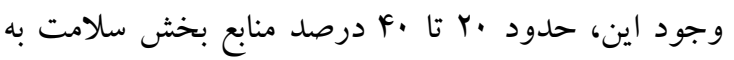

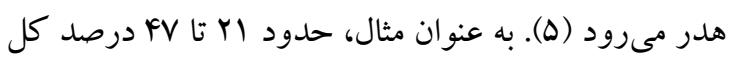

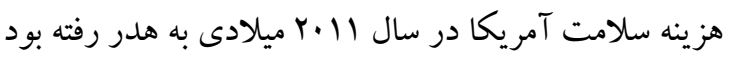

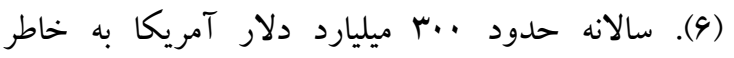
ناكارايى بيمارستانها در جهان از بين مىرود (V) افزايش بهرهورى سازمانهاى بهداشتى و درمانى بايد يكى از اهداف مهم نظام سلامت كشور تلقى شود.

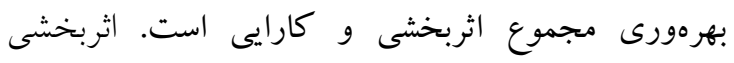
Effectiveness به معناى انجام كار درست و دستيابى به واته اهداف سازمانى است. كارايى Efficiency به معناى انجام درست كارها است، نسبت ستادهها به دادهها را نشان

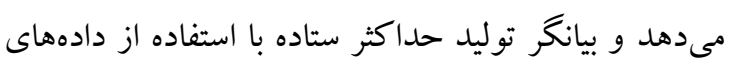
معين است. بيمارستان منابع متعددى نظير كاركنان،

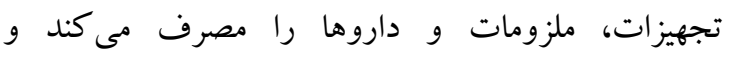
ستادههايى نظير ويزيت بيماران سريايى و بسترى و اعمال

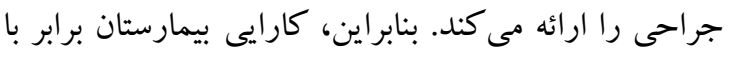
نسبت ارزش خدمات بهداشتى و درمانى ارائه شده به منابع استفاده شده است. در صورتى كه اين نسبت بيش از يك ورك باشد، بيانگر كارايى بيمارستان است. يكك مطالعه مرور نظاممند با بررسى و سنتز الو ئزهش انجام شده در زمينه

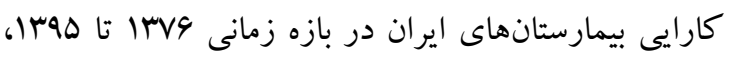

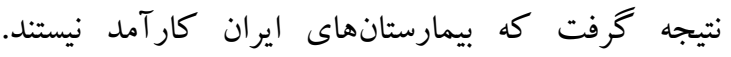

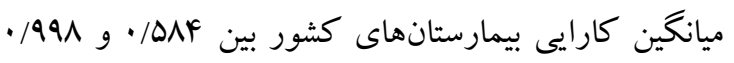
متغير بوده است (^). توجه به كارايى و بدست آوردن

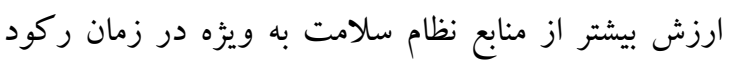

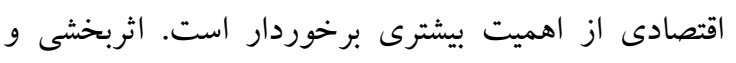

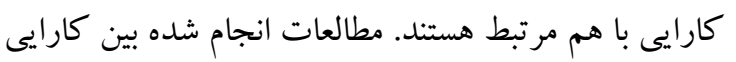

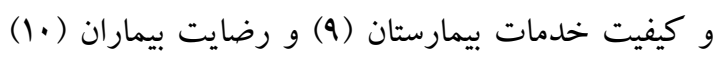
رابطه آمارى معنادارى يافتند.

كارايى به دو نوع كارايى تخصيصى و كارايى فنى تقسيم

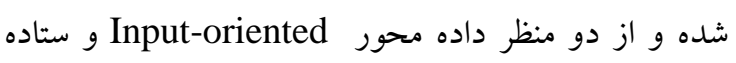

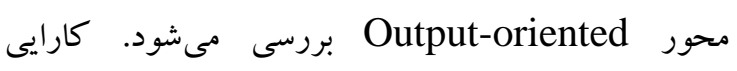
تخصيصى Allocative efficiency عبارت است از مُود
هزينه سلامت مردم جهان حدود V/A تريليارد دلار (حدود I.IV د درصد توليد ناخالص داخلى دنيا) در سال ميلادى بود. سرانه هزينه سلامت مردم دنيا در اين سال حدود •1 •1 دلار بود. رشد هزينهاى بخش سلامت به له مراتب بيشتر از رشد اقتصادى است. مخارج سلامت

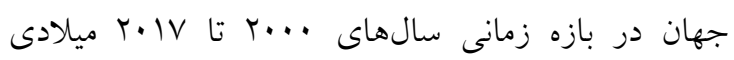
سالانه r/9 درصد رشد داشته است، در حالى كه، رشد اقتصادى سالانه ب درصد بوده است (1). هزينه سلامت در ايران نيز زياد است. حدود // درصد توليد ناخالص داخلى كشور در سال هوسا صرف هزينهاى سلامت مردم شد. ميانكين اين شاخص در دنيا و كشورهاى عضو منطقه مديترانه شرقى سازمان بهداشت جهانى به ترتيب 9/9 و س/ ه درصد بود. همجِنين، حدود Y/9 درصد بودجه عمومى دولت در اين سال صرف بخش سلامت شد، در حالى كه، ميانگين اين شاخص در دنيا و كشورهاى عضو منطقه مديترانه شرقى سازمان بهداشت جهانى 19/• و ـ/ه درصد بود (Y) (Y) بخش زيادى از بودجه نظام سلامت به بيمارستانها

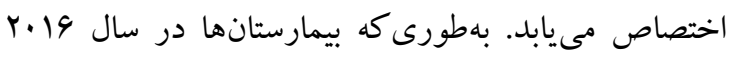
ميلادى، به طور متوسط حدود شM درصد هزينه كل سلامت كشورهاى عضو سازمان همكارى و توسعه اقتصادى را

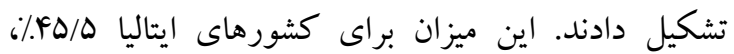
انگلستان / I/ F ب ب ده است. اين ميزان در كشورهاى با در آمد متوسط و

$$
\text { كم به مراتب بيشتر است (r). }
$$

هزينهاى بيمارستانى در دو دهه اخير به دليل افزايش جمعيت، بالا رفتن سن مردم جامعه، افزايش بيمارىهاى مزمن، توسعه يوشش بيمههاى سلامت، افزايش تقاضا براى

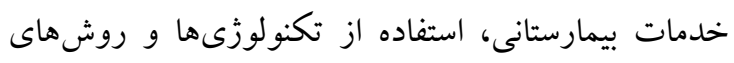
جديد و گرانقيمت تشخيصى و درمانى و افزايش خطاهاى يزشكى، افزايش جشمخيرى داشته است (F). منابع محدود بخش سلامت بِاسخ گوى نيازهاى نامحدود بيماران نيست. با بـ 
بيمارستان، تعداد بيمار درمان شده و هزينه تمام شده خدمات بيمارستانى، روشى ساده و آسان براى سنجش استفاده بهينه از ظرفيت بيمارستان است. به عنوان مثال، نمودار يابنلاسو كه در سال 1919 ميلادى توسط يابنلاسو استاد دانشگاهى در كلمبيا براى سنجش كارايى بيمارستانها معرفى شد، با استفاده از سه شاخص عملكردى درصد اشغال تخت، كردش تخت و طول اقامت بيماران، ميزان كارايى يك بيمارستان را در صفحهاى سه بعدى شامل جهار

$$
\text { ناحيه نشان مىدهد (I I). }
$$

در مقابل، روش تحليل يوششى دادهها از برنامهريزى رياضى و روش تحليل مرزى تصادفى از تكنيككهاى اقتصادسنجى و تابع توليد و هزينه براى ارزشيابى كارايى بيمارستانها Data استفاده مى كنند (A). روش تحليل يوششى دادهها Charness كه توسط جارنز Envelopment Analysis و همكاران در سال 19VA ميلادى معرفى شد، روشى غيريارامتريكك بر ويايه تكنيك برنامهريزى خطى است كه براى ارزشيابى كارايى سازمانهاى داراى جندين ورودى (داده) و خروجى (ستاده) به كار مىرود. در اين روش مجموع ستادهها بر مجموع دادهها تقسيم مىشود. تحليل يوششى دادهها، هر سازمانى را با كارآمدترين سازمان فرضى مقايسه مى كند. در اين روش بـ كمك دادههاى ارايه شده، مرزى به نام ”مرز كارايى“ در نظر كرفته مى شود و تمام سازمانهاى مورد بررسى، با اين مرز بهينه مقايسه مىشوند. اين روش نشان مىدهد كه آيا يك سازمان مىتواند با استفاده از همان ميزان داده، ستاده بيشترى توليد كند يا همان ميزان ستاده را با استغاده از داده كم توليد كند؟ تحليل بوششى دادهها يك امتياز بين صفر و يك به هر سازمان بر اساس ميزان منابع مصرفى و ستاده توليدى مى مهد و بر اساس آن مىتوان سازمانها را بر اساس كارايى رتبهبندى كرد. امتياز يخ نشانخر كارايى فنى بيمارستان در مقابل ساير بيمارستانهاى مورد بررسى است. امتياز كمتر از يك نشانخر ناكارايى بيمارستان است.
استفاده از تركيب بهينه عوامل توليد براى توليد ستاده مشخص (داده محور) يا تخصيص منابع محدود براى توليد كالاها و خدماتى كه بيشترين منفعت و مطلوبيت را براى جامعه داشته باشد (ستاده محور). كارايى فنى Technical در مقابل، استفاده از حداقل نهادهها براى توليد ميزان معين ستادهها (داده محور) يا توليد حداكثر ستاده با استفاده از مقدار معين نهادهها (ستاده محور) بدون توجه به ارزش ستادهها است (A). يكك بيمارستان زمانى از كارايى تخصيصى برخوردار است كه منابع بيمارستانى به گونهاى تخصيص يابد كه خدمات سلامت ارائه شده، اولويت جامعه بوده و حداكثر سلامتى و رضايت را براى مردم جامعه ايجاد كند. يكك بيمارستان زمانى از كارايى فنى برخوردار است كه يكك خدمت بسترى يا سربايى را با كمترين هزينه ممكن با استفاده از تركيبى از نيروى انسانى شايسته و تجهيزات

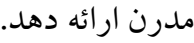
سياستخذاران و مديران نظام سلامت با افزايش هزينهاى بيمارستانى و كمبود منابع مالى، از دهه •191 ميلادى، توجه بيشترى به سنجش كارايى بيمارستانها و بكارگيرى اقداماتى براى كاهش اتلاف منابع بيمارستانى داشتند. اندازه گيرى كارايى بيمارستان به دليل ماهيت بيجيجيده ارائه خدمات و ناملموس بودن نتايج (سلامتى مردم) كار دشوارى است. بنابراين، عملكرد بيمارستانها را كمتر با شاخصهاى اقتصادى و مالى مانند رشد فروش، متوسط قيمت سهام، سود حسابدارى، نرخ باز گشت سرمايه، دوره بازگشت سرمايه، بازده خالص دارايى، سود باقيمانده، جريان نقدى و ارزش افزوده اقتصادى مىسنجند (1)). در مقابل، كارايى بيمارستانها را معمولاً با مقايسه منابع مورد استفاده و ستادههاى حاصل شده محاسبه مى كنند. از شاخصهاى عملكردى و تكنيككهاى مرزى اقتصاد خرد براى ارزشيابى كارايى فنى بيمارستانها استفاده مىشود (A). شاخصهاى عملكردى بيمارستانى نظير درصد اشغال تخت بيمارستان، متوسط اقامت بيمار در بيمارستان، گردش تخت 
امروزه دولت و سازمانهاى بيمه سلامت تأكيد زيادى بر خريد مبتنى بر ارزش Value based purchasing و يرداخت مبتنى بر عملكرد Pay for performance نسبت به خريد مبتنى بر كميت Volume based purchasing و بر برحت يرداخت مبتنى بر خدمت Fee for service دارند. مديران

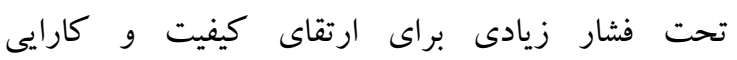
بيمارستانها هستند. افزايش هزينههاى بيمارستانى و تلاش

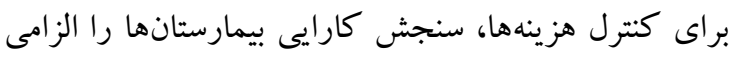

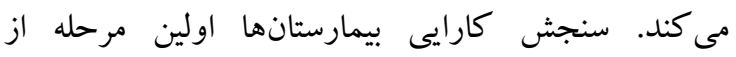

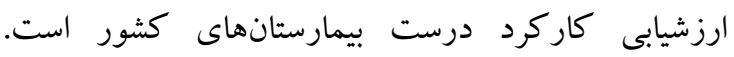

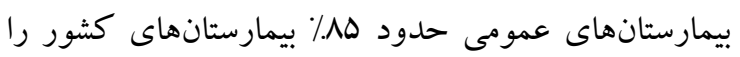
تشكيل مىدهند (IV). بنابراين، مطالعه حاضر با هدف ارزشيابى كارايى بيمارستانهاى عمومى كشور و شناسايى عوامل موثر بر كارايى اين بيمارستانها انجام شده است.

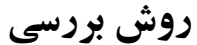

مطالعه حاضر از نوع مطالعات توصيفى - تحليلى است كه به به صورت مقطعى انجام شد. دادههاى آرشيوى شاخصهاى عملكردى بيمارستانهاى كشور در سال وها از وزارت

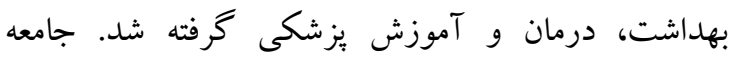
يُزوهش شامل تمام بيمارستانهاى عمومى كشور ايران است كه به روش سرشمارى وارد مطالعه شدند. در اين مطالعه از روش يابنلاسو براى ارزشيابى كارايى

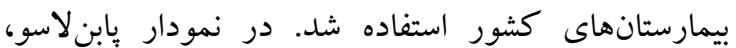
درصد اشغال تخت در محور افقى X و ميزان گردش تخت در محور عمودى Y نمايش داده مىشود (YI). ميزان درصد اشغال تخت، نسبت تخت روز اشغال شده به تخت روز فعال ضرب در ..1 و ميزان گردش تخت، نسبت تعداد مرخصشدكان و فوت شدكان به تخت فعال مىباشند. در

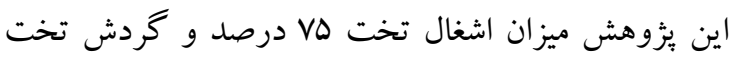
... بار به عنوان حد استاندارد و مرز ميان نواحى نمودار هابن لاسو در نظر گرفته شد. در نتيجه، جهار ناحيه در نمودار

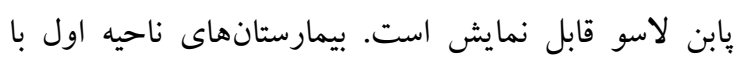

تفاوت بين عدد يكى و عدد حاصل از تحليل يوششى

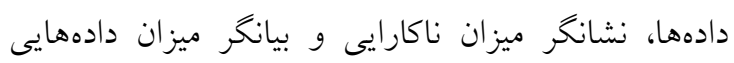
است كه بيمارستان مىتوانست صرفهجويى كند يا ميزان

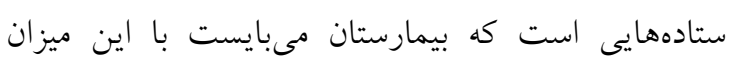

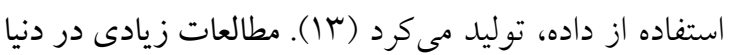
با استفاده از اين روش به ارزشيابى كارايى بيمارستانها

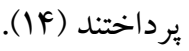

Stochastic Frontier روش تحليل تابع مرزى تصادفى

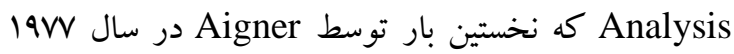
ميلادى معرفى شد، با بهره گيرى از مدلهاى اقتصادسنجى تخطى و تئورىهاى اقتصاد خرد به تخمين كارايى مى يردازد. كارايى يكك سازمان در اين روش بر اساس اختلاف ميان عملكرد مشاهده شده و ييشبينى شده آن سازمان محاسبه مىشود. در صورتى كه ميزان عوامل توليد و محصول يكك سازمان تصادفى باشد، تحليل مرزى تصادفى روش خوبى براى سنجش كارايى آن سازمان است (ها). اين شرايط در

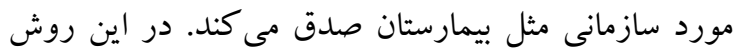
اخر عملكرد سازمانى كمتر از توليد مرزى باشد، قسمتى از

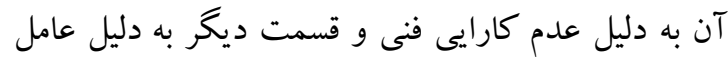
تصادفى است. از روش تحليل مرزى تصادفى در دهلى اخير در مطالعات متعددى براى ارزشيابى كارايى در بخش لشي سلامت استفاده شده است (19). متغيرهايى نظير تعداد تخت، تعداد كاركنان، ميزان ساعات كارى، متر مكعب ساختمان بيمارستان و هزينه كل توليد به عنوان متغيرهاى ورودى و متغيرهايى نظير تعداد بيماران اورزانسى، سريايى و بسترى ويزيت شده، تعداد اعمال

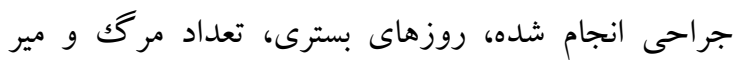

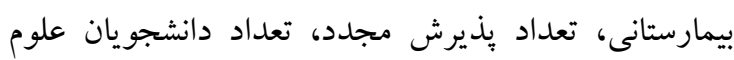

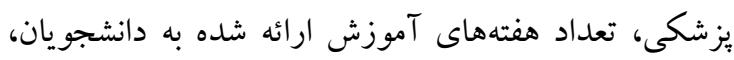
تعداد نشريات علمى منتشر شده و درآمد كل به به عنوان آنهان متغيرهاى خروجى، براى سنجش كارايى در روشهاى نشاي تحليل يوششى دادها و تحليل مرزى تصادفى استفاده

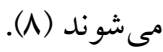


ناحيه جهارم با درصد اشغال تخت بيشتر و گردش تخت كمتر از حد استاندارد از كارايى متوسطى برخوردار هستند

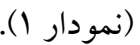

درصد اشغال تخت و ميزان كردش تخت كمتر از حد استاندارد، فاقد كارايى هستند. بيمارستانهاى ناحيه دوم با درصد اشغال تخت بايين و گردش تخت بالاتر از حد استاندارد، كارايى در حد متوسطى دارند. بيمارستانهاى ناحيه سوم با درصد اشغال تخت و كردش تخت بالا از كارايى مطلوبى برخوردار هستند. در نهايت، بيمارستانهاى

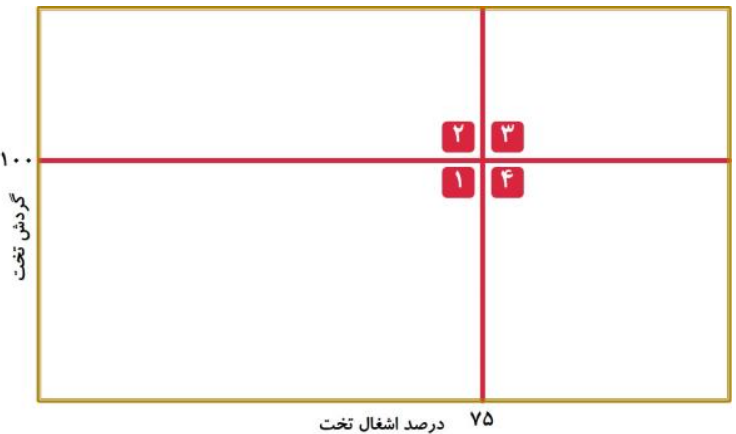

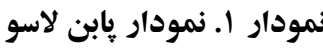

تعداد AYF بيمارستان عمومى با AYDV^• تخت فعال در پايان سال 94Mا در كشور وجود داشت. حدود 90 درصد تختهاى فعال بيمارستانى كشور متعلق به بيمارستانهاى

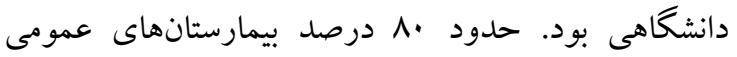
كشور از نوع درمانى بوده، MV درصد بيمارستانها بيش از

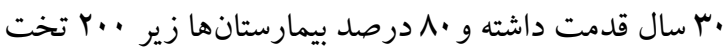
فعال داشتند. حدود بو درصد بيمارستانهاى عمومى كشور داراى Y تا F نفر كارمند به ازاى هر تخت فعال داشتند. ميانخين تخت فعال و كار كنان بيمارستانهاى عمومى كشور

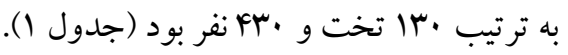

براى تحليل دادهها از آمار توصيفى و استنباطى با استفاده از نرمافزار SPSS استفاده شد. از شاخصهاى ميانگين و انحراف معيار براى توصيف دادهها و از آزمون آمارى آناليز واريانس براى آزمون فرضيات استفاده شد. از نرمافزار نيز براى ترسيم نمودار پيابن لاسو استفاده شد. ملاحظات اخلاقى و بىطرفى يزوهشخران در جمع آورى، تحليل و انتشار دادهها رعايت شد.

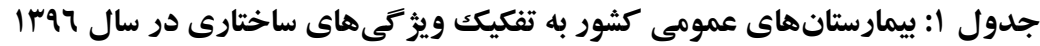

\begin{tabular}{|c|c|c|c|c|}
\hline \multicolumn{2}{|c|}{ تخت فعال } & \multicolumn{2}{|c|}{ بيمارستان عمومى } & \multirow[b]{2}{*}{ ويز حَى هاى ساختارى بيمارستانها } \\
\hline درصد & تعداد & درصد & تعداد & \\
\hline $94 / 9$ & V. rMF & $4 \cdot / 4$ & $\Delta \cdot r$ & دانشعاه علوم يزشكى \\
\hline $14 / 0$ & 10909 & $\mathrm{IV} / \mathrm{V}$ & $\mid F \wedge$ & بخش خصوصى \\
\hline $9 / 9$ & 1.ra. & $\Lambda / F$ & v. & سازمان تأمين اجتماعى \\
\hline$f / q$ & DrIG & $9 / \pi$ & $\Delta r$ & نيروهاى مسلح \\
\hline$r / \mathrm{V}$ & f.rq & $f / r$ & ra & سازمان هاى خيريه \\
\hline$\cdot / r$ & Mil & $\cdot / f$ & $r$ & بنياد شهيد و امور ايثاركران \\
\hline$\cdot / 9$ & 990 & $1 / 1$ & 9 & شر كت نفت \\
\hline$\cdot / f$ & 491 & $\cdot 19$ & $\Delta$ & دانشعاه آزاد اسلامى \\
\hline
\end{tabular}

هجلم علمى دانشكاه علوه بِزشكى كردستان / دوره بيست و شش / درداد و شهريور م.عاן 


\begin{tabular}{|c|c|c|c|c|c|}
\hline$\cdot / \wedge$ & 911 & $\cdot / \Lambda$ & V & ساير سازمان ها & \\
\hline $4 \cdot / 4$ & $9 \Delta Y \cdot Y$ & Vq/a & 994 & درمانى & مأموريت \\
\hline $\mathrm{rq} / \mathrm{\Lambda}$ & $\mu r \cdot \Delta \Delta$ & $r \cdot / 1$ & 191 & آموزشى، درمانى و يخوهشى & \\
\hline $14 / 9$ & $\mid \Delta \wedge F \Lambda$ & $r y / r$ & IVV & كمتر از • ا سال & \\
\hline$r \Delta / \Delta$ & rVGFq & $r \Delta / 1$ & $r \cdot 9$ & ا تا •r سال & \\
\hline $10 / 1$ & $I V \cdot \Delta r$ & $19 / V$ & If. & اب تا •r سال & قدمت \\
\hline $1 \cdot / 4$ & IIrVA & $9 / \cdot$ & VD & اس تا •ع سال & \\
\hline$I Y / V$ & Irvqd & $11 / 1$ & 91 & اع تا •0 سال & \\
\hline $\mathrm{V} / \mathrm{V}$ & NTrV & $\mathrm{V} / \cdot$ & $\Delta \wedge$ & ا 0 تا • 7 سال & \\
\hline $1 \% / r$ & IFYAN & $9 / r$ & VV & بيشتر از • ل سال & \\
\hline$r \cdot / \Lambda$ & rrorl & $0 \cdot / 1$ & Fin & تا • • ا تخت & \\
\hline$r \Delta / \Delta$ & MAFV. & $\mathrm{rT/V}$ & rVF & 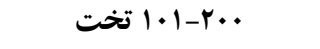 & \\
\hline re/V & rMMAY & $\mid r / r$ & 11. & 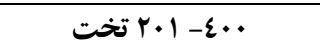 & 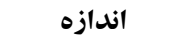 \\
\hline $9 / r$ & $99 \cdot V$ & $r / \Delta$ & YI & . . .-1.ع تخت & \\
\hline $\mathrm{V} / \mathrm{\Lambda}$ & $\Lambda F \Delta V$ & $1 / r$ & 11 & بالاتر از ا.ح تخت & \\
\hline$\wedge / 9$ & QGYF & $\Lambda / V$ & $V r$ & كمتر از r نفر & تعداد كارمند به \\
\hline$v$. & VDSQ9 & $9 Y / 1$ & $\Delta 11$ & ب آتا ع نفر & ازاى تخت \\
\hline$M / Y$ & $19 \wedge \Delta \wedge$ & $r F / r$ & $r \cdot r$ & ع تا ר نقر & \\
\hline$r / 9$ & $r .9 F$ & $r / 9$ & f. & ح تا م نفر & \\
\hline
\end{tabular}

فارس (V/I درصد) و خر اسان رضوى ( • V/ درصد) بيشترين و استانهاى ايلام و كهخلويه و بويراحمد (^/• درصد) و بوشهر (1/1 درصد) كمترين تعداد تخت فعال را داشتند

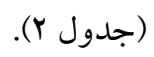

بيشتر بيمارستانهاى عمومى در استانهاى تهران (ه/هان درصد)، فارس (1 درصد) و اصفهان (4/9 درصد) و كمترين بيمارستانهاى عمومى در استانهاى قم (1 درصد)، كهكلويه و بوير احمد (1/1 درصد) و جهارمحال و بختيارى (ا/ درصد) قرار داشت. استانهاى تهران (س/·r درصد)،

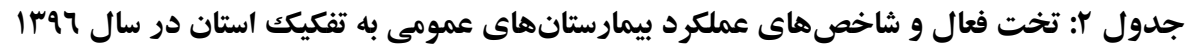

\begin{tabular}{|c|c|c|c|c|c|c|c|}
\hline \multirow{2}{*}{ تخرش } & \multirow{2}{*}{ ماقدت } & \multirow{2}{*}{ 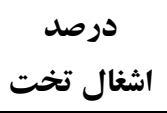 } & \multicolumn{2}{|c|}{ تخت فعال } & \multicolumn{2}{|c|}{ بيمارستان عمومى } & \multirow[b]{2}{*}{ استان } \\
\hline & & & درصد & تعداد & درصد & تعداد & \\
\hline$\vee \vee / \Lambda$ & $r / r$ & $V Y / I$ & $r \cdot / r$ & rlars & $10 / 0$ & 1199 & تهران \\
\hline$Q F / F$ & $r / F$ & $99 / \pi$ & $V / I$ & VGrq & $\Lambda /$ & $9 V$ & فارس \\
\hline $1 \cdot 0 / 9$ & $r / r$ & 9N/V & $\Delta / \Lambda$ & GMYA & $9 / 9$ & $\Delta \Delta$ & اصفهان \\
\hline $1 \cdot 1 / 9$ & $r / F$ & $V I / Y$ & $\mathrm{~V} / \cdot$ & $V \Delta \Delta V$ & $9 / 4$ & $\Delta r$ & خر اسان رضوى \\
\hline$Q \Delta / \Delta$ & $Y / V$ & $99 / \pi$ & 91. & $949 V$ & $\Delta / \Lambda$ & FA & خوزستان \\
\hline $9 Y / 9$ & $r / \Lambda$ & $V 1 / 9$ & $4 / 1$ & FFVr & $F / V$ & rq & مازندران \\
\hline$\wedge 9 / \wedge$ & $r / 9$ & $99 / \pi$ & $r / V$ & $f \ldots k$ & $F / 1$ & rF & آذربايجان شرقى \\
\hline $9 F / \Lambda$ & Y/9 & $9 \mathrm{~V} / 9$ & $r / \Lambda$ & $F \cdot M$ & $r / \Lambda$ & HY & كرمان \\
\hline $9 Y / \Delta$ & $r / V$ & $99 / 4$ & $r / 9$ & 1111 & $r / 9$ & $r$. & تيلان \\
\hline $1 \cdot V / F$ & $r / 9$ & $V \Lambda / r$ & $r / N$ & 4.11 & $r / \Delta$ & rq & آذربايجان غربى \\
\hline 19/9 & $r / 9$ & $V \pi / r$ & $Y / \cdot$ & Yr.r & $r / \Lambda$ & $r r$ & لرستان \\
\hline $1.9 / \cdot$ & $r / \Delta$ & V9/. & $r / r$ & YFVF & $Y / 9$ & rY & كلستان \\
\hline $1 \cdot 1 / \Lambda$ & $Y / Y$ & $99 / r$ & $1 / \Lambda$ & $191 \mathrm{~V}$ & $Y / F$ & r. & هرمز كان \\
\hline $\mid r r / 1$ & $Y / Y$ & $\mathrm{Vq} / \cdot$ & $r / r$ & rorV & $r / r$ & 19 & سيستان و \\
\hline
\end{tabular}




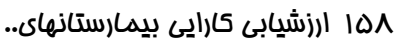

\begin{tabular}{|c|c|c|c|c|c|c|c|}
\hline & & & & & & & بلوجستان \\
\hline $11 / r$ & $r / \Lambda$ & $90 / 4$ & $1 / 1$ & 1949 & $r / r$ & 19 & مركزى \\
\hline$\Lambda \Lambda / F$ & $T / V$ & $9 N / 9$ & $r / F$ & raf. & $Y / Y$ & 11 & همدان \\
\hline$\wedge q / r$ & $r / V$ & $99 / 1$ & $r / l$ & rHYS & $r / \cdot$ & IV & كردستان \\
\hline $11 \cdot \%$ & $r / r$ & $V I / \Lambda$ & $r / \cdot$ & $r / 90$ & $r / \cdot$ & IV & كرمانشاه \\
\hline $99 / V$ & $r / \Delta$ & $V \backslash / \cdot$ & $r / F$ & ra11 & $r / \cdot$ & IV & يزد \\
\hline $99 / 1$ & $r / 9$ & $V F / \cdot$ & $r / Y$ & YFMT & $1 / 9$ & 19 & البرز \\
\hline$\Lambda \Delta / \wedge$ & $r / 9$ & $9 N / 1$ & $1 / \Gamma$ & IFY. & $1 / \Lambda$ & 10 & خراسان جنوبى \\
\hline $9 F / F$ & $r / \mu$ & $9 \cdot / 9$ & $1 / 1$ & IYFT & $1 / \wedge$ & 10 & بوشهر \\
\hline $91 / 1$ & $r / 9$ & $V Y / \Delta$ & $1 / 0$ & 194. & $1 / V$ & if & اردبيل \\
\hline$\wedge 9 / 1$ & $Y / V$ & $9 \mathrm{~V} / 9$ & $1 / 9$ & $19 \times 9$ & $1 / 9$ & ir & قزوين \\
\hline$\Lambda \Delta / r$ & $r / \mu$ & $\Delta N / 9$ & $\cdot / \Lambda$ & AVD & $1 / 4$ & ir & ايلام \\
\hline$V Q / Y$ & $T / V$ & $V I / \Delta$ & $1 / r$ & $1 r 99$ & $1 / 4$ & Ir & خراسان شمالى \\
\hline $1 N / 9$ & $r / \Lambda$ & $V \Delta / \Delta$ & $1 / 9$ & 199. & $1 / 4$ & ir & زنجان \\
\hline $91 / 1$ & $T / V$ & $9 N / \Gamma$ & $1 / 4$ & 1499 & $1 / r$ & 11 & سمنان \\
\hline$|r| / r$ & $r / r$ & $\Delta r / r$ & $1 / r$ & $|f| 9$ & $1 / 1$ & 9 & بختيارى \\
\hline$\wedge 1 /$. & $r / 9$ & $99 / \mathrm{V}$ & $\cdot / \wedge$ & 9.4 & $1 / 1$ & 9 & بويراحملويه و \\
\hline$\Lambda 1 /$. & $\mu /$ & $v \cdot / \cdot$ & $1 / 0$ & IGYV & $1 / \cdot$ & $\wedge$ & قم \\
\hline $9 \mu / F$ & $r / 9$ & $9 Y / \Lambda$ & $1 \ldots$ & $1 \cdot \Lambda r \Delta V$ & $1 \cdots$ & $\Delta r F$ & مجموع \\
\hline
\end{tabular}

ميانگين گردش تخت بيمارستانها به بار و ميانگين فاصله ميانگين اشغال تخت بيمارستانهاى عمومى كشور GY/A گردش تخت بيمارستانها ץ روز بوده است (جدول r).

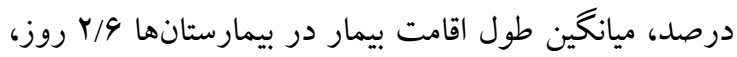

جدول זّ: شاخصهاى عملكردى بيمارستانهاى عمومى كشور در سال 1 17

\begin{tabular}{|c|c|c|}
\hline انحراف معيار & ميانگين & شاخص \\
\hline $11 / 1$ & GY/A & درصد اشغال تخت \\
\hline $1 / 9$ & $T / 9$ & طول اقامت بيمار \\
\hline$r V / r$ & $9 \pi / 4$ & كردش تخت \\
\hline$T / T$ & $\mathrm{~T} / \cdot$ & فاصله گُردش تخت \\
\hline
\end{tabular}

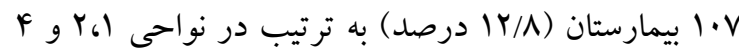

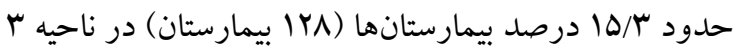
نمودار يابن لاسو قرار داشتند (نمودار Y).

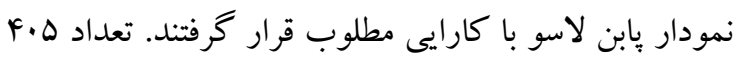
بيمارستان (F//9 درصد)، $19 F$ بيمارستان (س/Fr/9 درصد) و 


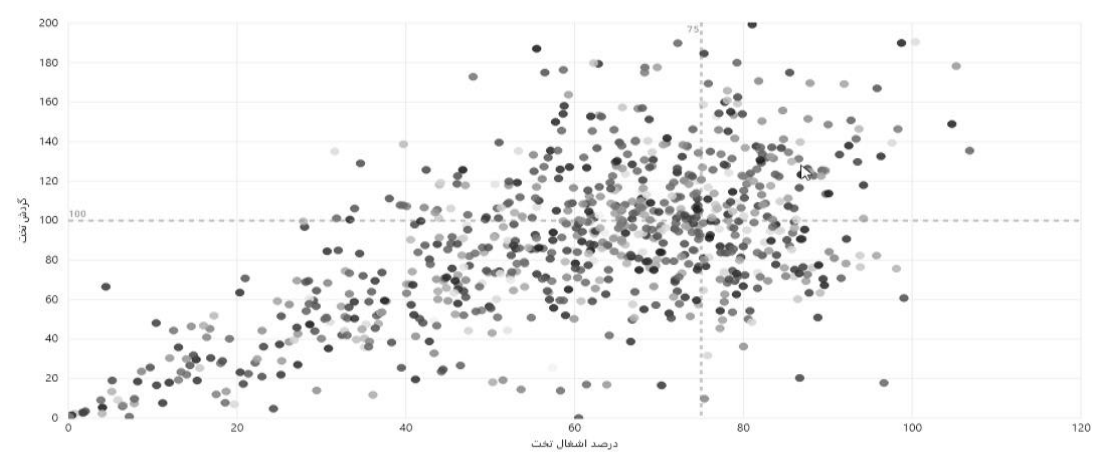

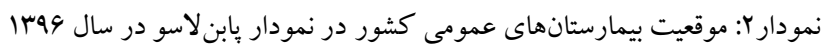

نمودار ب عملكرد بيمارستانهاى هر استان را در نمودار بابن لاسو قرار دارند و كارايى آنها خيلى كم است.

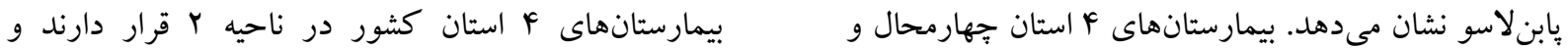

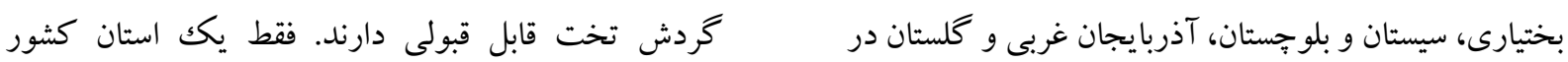

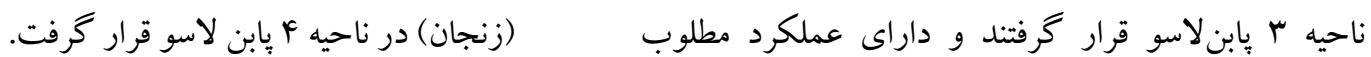
بودند. بيمارستانهاى r r استان كشور در ناحيه يكك نمودار

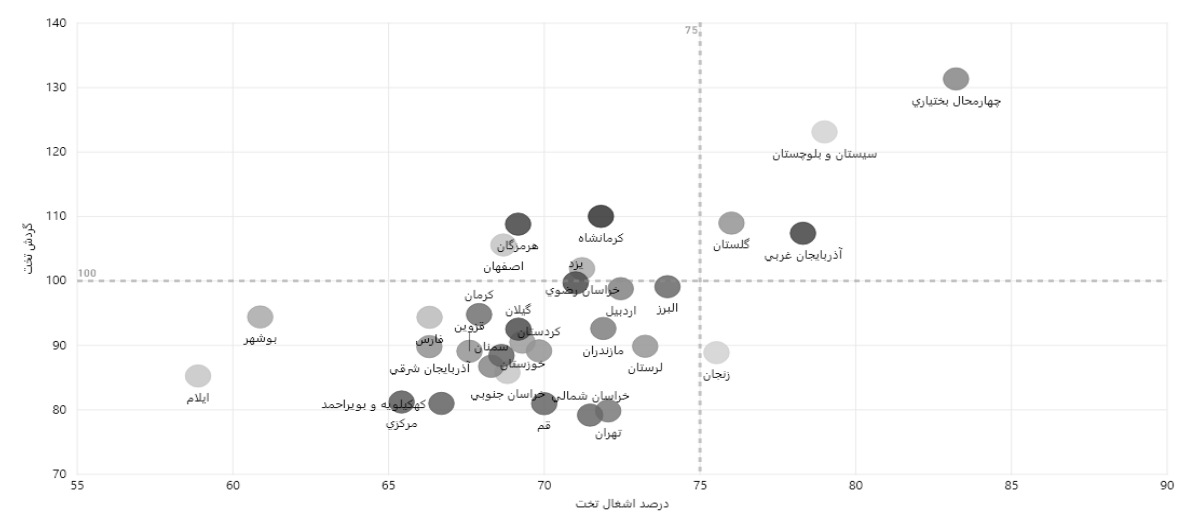

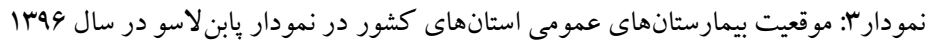

در ناحيه دو نمودار يابنلاسو قرار دارند. از بين f استانى كه عملكرد به نسبت بهترى دارند، يعنى در ناحيه ب يابن لاسو قرار گرفتهاند، ب استان مرزى هستند.
نمودار F وضعيت بيمارستانهاى استانهاى كشور را از نظر قرارگيرى در نمودار بابنلاسو نشان مىدهد. بيمارستانهاى

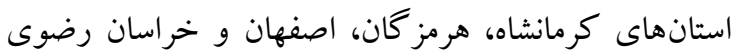




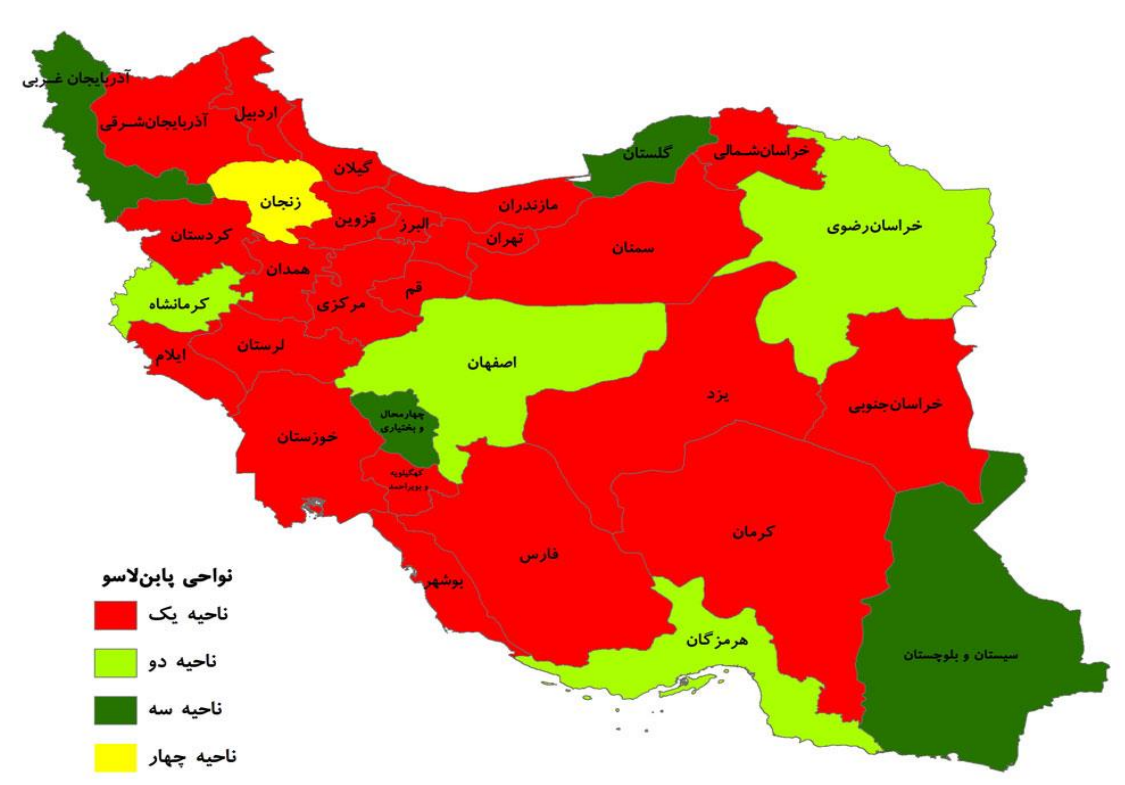

نمودار ץ: نقشه موقعيت بيمارستانهاى عمومى استانهاى كشور در نمودار يابن لاسو در سال 94سا

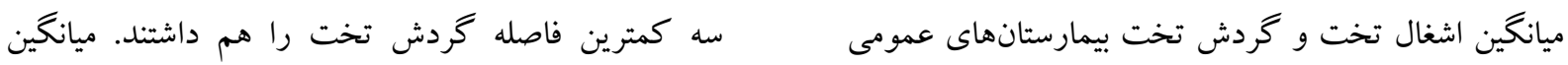

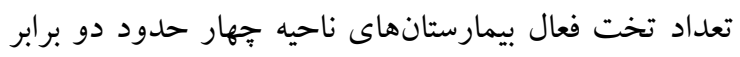

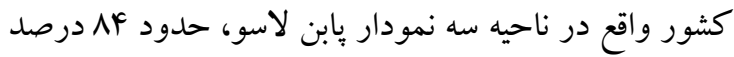
تخت هاى بيمارستانهاى ناحيه ب بود (جدول \&). و ربا بار بود. گردش تخت بيمارستانهاى ناحيه سه تقريباً دو برابر بيمارستانهاى ناحيه يكك است. بيمارستانهاى ناحيه

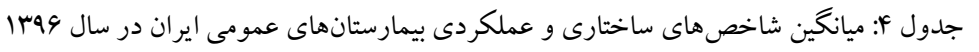

\begin{tabular}{|c|c|c|c|c|c|c|c|c|}
\hline تعداد كار كنان & كار كنان & تخداد & بيمارستان & كردش تخت & تخرش & اقامت & درصد اشغال & نابن لإسو \\
\hline$r / \Delta$ & MIr & ar & ro & $r / l$ & $99 / 1$ & $r / V$ & $\Delta 1 / r$ & ناحيه يكى \\
\hline$r / \Lambda$ & ral & $1 \cdot 1$ & rq & $1 / 1$ & $|r r /|$ & $1 / 9$ & $9 Y / 1$ & ناحيه دو \\
\hline$r / \mathcal{F}$ & 0.1 & 101 & rV & $\cdot / f$ & $1 \pi V / 9$ & $r / r$ & $\Delta F / 1$ & ناحيه سه \\
\hline$\mu / \cdot$ & 199 & rA9 & f. & $\cdot / 9$ & $v 9 / 9$ & $F / r$ & $\Lambda Y / V$ & ناحيه جֶهار \\
\hline
\end{tabular}

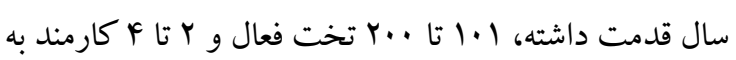
ازاى هر تخت فعال داشتند. به ترتيب، درصد از بيمارستانهاى درمانى در نواحى ا، Y و r نمودار يابن لاسو قرار كرفتند. بيشتر بيمارستانهاى كمتر از . ..1 تخت (4/4 دروصد) در ناحيه يك بابن لاسو قرار گرفتند. به

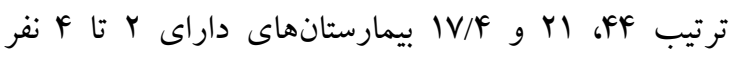
كارمند به ازاى تخت، در نواحى ا، r و r قرار كرفتند

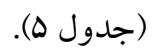

تمامى بيمارستانهاى شركت نفت و دانشگاه آزاد اسلامى در ناحيه يكك يابنلاسو با درصد اشغال تخت و گردش

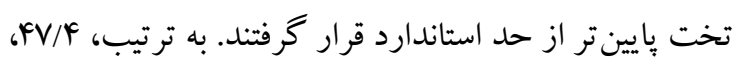

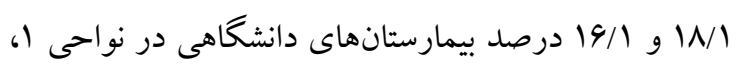

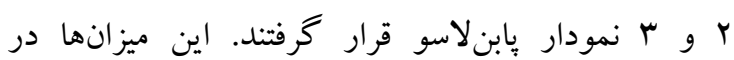
بيمارستانهاى خصوصى •ه، MV/A و I/ / 1 درصد و براى

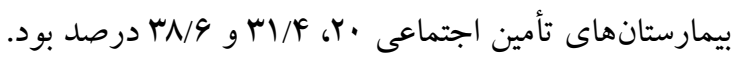

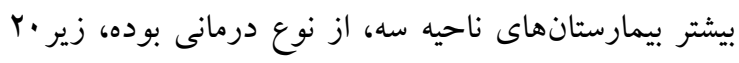


جدول ه: توزيع فراوانى بيمارستانهاى عمومى كشور در نواحى يابن لاسو به تفكيك ويزگى هاى ساختارى در سال وهبا

\begin{tabular}{|c|c|c|c|c|c|}
\hline تعداد (درصد جهار & تعداد (درصد) & تعداد (درصد) & تعداد (درصد يك & ى ساختارى بيمارستانها & ويثزى هاز \\
\hline$q \mu(\mid \Lambda / f)$ & $11(19 / 1)$ & $91(1 / / 1)$ & $Y M Q(F V / F)$ & دانشكاء علوم يزشكى & \multirow{8}{*}{ مالكيت } \\
\hline$r(r / \cdot)$ & $10(1 \cdot / 1)$ & $\Delta \varphi(r V / \Lambda)$ & $\operatorname{VF}(\Delta \cdot / \cdot)$ & بخش خصوصى & \\
\hline$v(1 \cdot / \cdot)$ & $r V(Y N / 9)$ & $r Y(r M / F)$ & $\mid F(Y \cdot / \cdot)$ & سازمان تأمين اجتماعى & \\
\hline$r(\boldsymbol{F} / \cdot)$ & $r(9 / \cdot)$ & $\mid F(Y N / \cdot)$ & $M(G Y / \cdot)$ & نيروهاى مسلح & \\
\hline$\cdot(\cdot / \cdot)$ & $r(\Delta / 9)$ & $\Lambda(Y Y / Y)$ & $r G(V Y / Y)$ & سازمان هاى خيريه & \\
\hline$\cdot(\cdot / \cdot)$ & $\cdot(\cdot / \cdot)$ & $\cdot(\cdot / \cdot)$ & $9(1 \cdot \cdot / \cdot)$ & شر كت نفت & \\
\hline$\cdot(\cdot / \cdot)$ & $\cdot(\cdot / \cdot)$ & $\cdot(\cdot / \cdot)$ & $\Delta(1 \cdot \cdot / \cdot)$ & دانشگاه آزاد اسلامى & \\
\hline$r(19 / \mathrm{V})$ & $\cdot(\cdot / \cdot)$ & $r(Y \Delta / \cdot)$ & $V(\Delta \Lambda / \Gamma)$ & ساير سازمان ها & \\
\hline$r q(\Delta / \mathcal{F})$ & $1 \cdot r(1 \Delta / \Delta)$ & $\operatorname{IVG}(Y G / F)$ & $\operatorname{r\Delta l}(\Delta \mathrm{V} / \mathrm{V})$ & 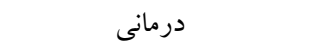 & \multirow[t]{2}{*}{ مأموريت } \\
\hline$V I(F Y / Y)$ & $r \Delta(\mid F / q)$ & $M(1 \cdot / v)$ & $\Delta F(r Y / Y)$ & آموزشى، درمانى و يثزوهشى & \\
\hline $\operatorname{lf}(V / 9)$ & $\operatorname{lr}(\boldsymbol{g} / \mathrm{A})$ & $\operatorname{Mr}(1 / / 1)$ & $119(9 V / Y)$ & كمتر از • اسال & \multirow{7}{*}{ قدمت } \\
\hline$r \cdot(9 / 9)$ & $F q(Y Y / \cdot)$ & $F q(Y r / F)$ & $q F(F \Delta / \cdot)$ & التا •r سال & \\
\hline $9(9 / 4)$ & $M Y(Y Y / Q)$ & $\Delta 1(K G / F)$ & $F \wedge(F r / r)$ & ابr •r سال & \\
\hline $\mathbb{I r}(\mathrm{IV} / \Gamma)$ & $V(9 / \Gamma)$ & $Y I(Y N / I)$ & $\mu F(F \Delta / \Gamma)$ & ابتا •Fال & \\
\hline $19(19 / 4)$ & $19(19 / \Gamma)$ & $19(19 / 4)$ & $F F(F F / q)$ & أFا •ه سال & \\
\hline $9(10 / \Delta)$ & $V(I Y / I)$ & $I F(Y F / I)$ & $\curlyvee \wedge(F \wedge / \Gamma)$ & اله تا •9 سال & \\
\hline$r \mu(Y Q / Q)$ & $\Lambda(1 \cdot / \mathscr{F})$ & $\Lambda(1 \cdot / 4)$ & $\mu \wedge(F q / \mu)$ & بيشتر از ·9 سال & \\
\hline $19(r / \Lambda)$ & $r \cdot(V / r)$ & $1.9(Y \Delta / F)$ & $r 99(94 / 9)$ & كمتر از ..1. & \multirow{5}{*}{ تحداد } \\
\hline$r q(1 \cdot 19)$ & $V G(Y V / V)$ & $G \Lambda(Y K / \Lambda)$ & $1.1(14 / 9)$ & r.. & \\
\hline$r V(r / 9)$ & $r \cdot(I N / Y)$ & $19(1 \mathrm{~V} / \mathrm{T})$ & $\mu F(r \cdot / q)$ & f.. I r.l & \\
\hline $19(V q / Y)$ & $1(F / \Lambda)$ & $I(F / \Lambda)$ & $r(I F / Y)$ & G.. I & \\
\hline $9(\Lambda) / \Lambda)$ & $1(9 / 1)$ & $\cdot(\cdot / \cdot)$ & $1(9 / 1)$ & بالاتر از 4.1 & \\
\hline$V(9 / 9)$ & $19(1 Y / V)$ & $\mid r(\mid \Lambda / Y)$ & $F Y(\Delta Q / Y)$ & كمتر از ب نفر & \multirow{4}{*}{ كار كنان به } \\
\hline $91(1 V / 9)$ & $q \cdot(I V / F)$ & $1.9(Y) / \cdot)$ & TYA $(F F / \cdot)$ & Y أا Fن & \\
\hline$q(F / F)$ & $r \Delta(\mid r / \Gamma)$ & $4 \cdot(Y 9 / 9)$ & $1.9(\Delta \mathrm{r} / \mathrm{V})$ & F أتا و نفر & \\
\hline$\cdot(\cdot / \cdot)$ & $F(1 \cdot / \cdot)$ & $\mid r(r \cdot / \cdot)$ & $F F(\xi \cdot / \cdot)$ & و تا م نفر & \\
\hline
\end{tabular}

تعداد كاركنان بيمارستانها و شاخصهاى درصد اشغال تخت، طول مدت اقامت و فاصله گردش تخت از نظر

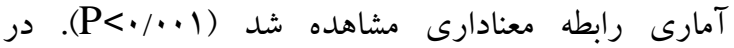
بيمارستانهاى داراى Y تأ F كارمند به ازاى تخت فعال، ميزان اشغال تخت، بيشترين (9D/V درصد) و فاصله گردش تخت كمترين (V/V روز) بوده است.
بين قدمت بيمارستانها با هر جهار شاخص عملكردى ارتباط معنادارى وجود دارد (ه•/P>•(P). مدت اقامت بيماران و كردش تخت در بيمارستانهاى بالاتر از •ه سال بيشتر است. درصد اشغال تخت در بيمارستانهاى جديد كمتر و در 1. بيمارستانهاى قديمى بيشتر است. بيمارستانهاى زير سال، بيشترين فاصله گردش تخت را دارا مىباشند. بين 
بيماران و فاصله گردش تخت بالاترى دارند و اين تفاوت از

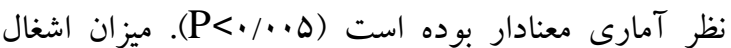
تخت در بيمارستانهاى با بيش از · .9 تخت نسبت به ساير بيمارستانها بيشتر و در بيمارستانهاى با زير ..1 تخت، كمتر است. طول اقامت بيماران در بيمارستانهاى كمتر از . . . تخت، نسبت به ساير بيمارستانهاى عمومى كمتر است.

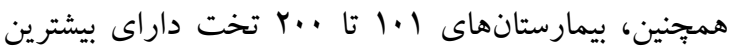
كردش تخت و بيمارستانهاى بيش از . .9 تخت داراى كمترين فاصله گردش تخت هستند. اين تفاوتها نيز از نظر آمارى معنادار بود (جدول 9)
اختلاف آمارى معنادارى در ميانخين اشغال تخت، طول اقامت بيماران و فاصله گردش تخت بيمارستانها به تفكيك نوع مالكيت مشاهده شد ( (P</. P). بيمارستانهاى دانشكاه علوم يزشكى بيشترين اشغال تخت و بيمارستانهاى بنياد شهيد بيشترين طول اقامت بيماران را داشتند. بيمارستانهاى خصوصى كمترين طول اقامت بيماران را دارا مىباشند. فاصله گردش تخت در بيمارستانهاى تأمين اجتماعى نسبت به ساير بيمارستانها كمتر است.

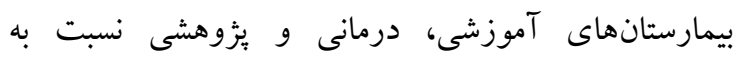
بيمارستانهاى درمانى، درصد اشغال تخت، طول اقامت

جدول 9: ميانخين و انحر اف معيار شاخص هاى عملكردى بيمارستانهاى عمومى به تفكيك ويز گى هاى ساختارى

\begin{tabular}{|c|c|c|c|c|c|c|c|c|c|}
\hline $\begin{array}{c}\text { P- } \\
\text { Value }\end{array}$ & تخرش تخله & $\begin{array}{c}\text { P- } \\
\text { Value }\end{array}$ & تخرش & $\begin{array}{c}\text { P- } \\
\text { Value }\end{array}$ & متوسط & $\begin{array}{c}\text { P- } \\
\text { Value }\end{array}$ & تخدال & بيمارستانى ساختارى & \\
\hline \multirow{9}{*}{$<\cdot / \cdot \cdot 1$} & $1 / \wedge(1 / 9)$ & \multirow{9}{*}{$\cdot / 1 T V$} & $91 / \Delta(\Gamma / \Lambda)$ & \multirow{9}{*}{$<\bullet / \cdot \cdot 1$} & $r / \Lambda(1 / f)$ & \multirow{9}{*}{$<\cdot / \cdot \cdot 1$} & $99 / \cdot(\mathrm{IV} / \mathrm{N})$ & دانشكاه علوم يزشكى & \multirow{9}{*}{ مالكيت } \\
\hline & $r / Y(Y / Y)$ & & $1 \cdots / V(F r / q)$ & & $Y / Y(1 / \Gamma)$ & & $\Delta \Delta / Y(\mid \Lambda / F)$ & بخش خصوصى & \\
\hline & $1 / \cdot(\cdot / 9)$ & & $11 \cdot /(Y \wedge / \cdot)$ & & $r / \Delta(\cdot / 9)$ & & $V \Psi / F(\mid r / \Lambda)$ & سازمان تأمين اجتماعى & \\
\hline & $r / 9(r / Y)$ & & $\Lambda V / F(F q / \Gamma)$ & & $Y / V(Y / \cdot)$ & & $\Delta \varphi / \mathcal{F}(\mid q / \Lambda)$ & نيروهاى مسلح & \\
\hline & $r / \Lambda(Y / V)$ & & $\Lambda V / \Lambda(F \mid / 9)$ & & $r / Y(1 / 1)$ & & $0 \cdot / \cdot(19 / 1)$ & سازمان هاى خيريه & \\
\hline & $F / I(F / F)$ & & $G F / F(F \wedge / F)$ & & $1 . / 9(1 F / 9)$ & & $90 / 9(1 . / 9)$ & بنياد شهيد & \\
\hline & $\Delta / \Gamma(\Gamma / \Delta)$ & & $\Delta F / T(Y) / \Lambda)$ & & $r / 9(\cdot / \Lambda)$ & & $\mathrm{rV} / \cdot(I r / \Delta)$ & شركت نفت & \\
\hline & $\Gamma / \Gamma(Y / \Gamma)$ & & $99 / Y(1 \Lambda / V)$ & & $r / \Gamma(\cdot / \Delta)$ & & $F \Delta / /(I V / 9)$ & دانشگاه آزاد اسلامى & \\
\hline & $\Gamma / 9(\Gamma / \cdot)$ & & $V \cdot / l(F \mid / \Lambda)$ & & $r / \Delta(\cdot / 9)$ & & $F V / 9(19 / 9)$ & ساير سازمان ها & \\
\hline \multirow[t]{3}{*}{$<\cdot / \cdot \cdot 1$} & $1 / Y(1 / 1)$ & \multirow[t]{3}{*}{$<\cdot / \cdot \Delta$} & $9 \Delta / \Gamma(\Gamma \wedge / \mathcal{F})$ & \multirow[t]{3}{*}{$<\cdot / \cdot \cdot 1$} & $r / F(1 / \Delta)$ & \multirow[t]{3}{*}{$<\cdot / \cdot \cdot 1$} & $9 \cdot / \cdot(1 / / 9)$ & درمانى & \multirow[t]{3}{*}{ مأموريت } \\
\hline & $r / I(Y / F)$ & & $\wedge 9 / 1(\Gamma / / 9)$ & & $r / f(1 / 9)$ & & $V F / Y(I Y / Y)$ & آموزشى، درمانى و & \\
\hline & & & & & & & & 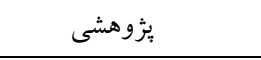 & \\
\hline \multirow{9}{*}{$<\cdot / \cdot \Delta$} & $r / \Delta(Y / V)$ & \multirow{7}{*}{$<\cdot / \cdot \cdot 1$} & $\Lambda F / Q(r G / \Gamma)$ & \multirow{7}{*}{$<\cdot / \cdot \Delta$} & $r / \Delta(\cdot / 9)$ & \multirow{7}{*}{$<\cdot / \cdot \cdot 1$} & $\Delta V / \mu(\mid \Lambda / 9)$ & كمتر از • ا سال & \multirow{7}{*}{ قدمت } \\
\hline & $1 / V(1 / 9)$ & & $9 \Lambda / \mathrm{V}(\mathrm{rV} / \cdot)$ & & $r / \Delta(1 / 9)$ & & $q 4 / \Gamma(1 / / 9)$ & 1ا تا •r سال & \\
\hline & $1 / 9(1 / 0)$ & & $1 . F / G(Y K / I)$ & & $r / F(Y / Y)$ & & $q 4 / I(I V / I)$ & ابr •rسال & \\
\hline & $1 / 9(Y / I)$ & & $q F / \Delta(r \Delta / \varphi)$ & & $r / \Delta(1 / \cdot)$ & & $91 / \Delta(1 \Lambda / r)$ & 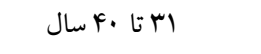 & \\
\hline & $1 / \Lambda(Y / Y)$ & & $Q Y / F(F \cdot / F)$ & & $r / \Lambda(1 / 9)$ & & $9 \Delta / f(19 / \Delta)$ & أFا •ه سال & \\
\hline & $Y / \cdot(Y / Y)$ & & $\Lambda V / \Delta(\Gamma Q / Q)$ & & $\Gamma / I(Y / \mathcal{F})$ & & $94 / \cdot(1 N / 9)$ & اله تا •9 سال & \\
\hline & $Y / \cdot(Y / Y)$ & & $\Lambda \Gamma / \Gamma(\Gamma / / 9)$ & & $\Gamma / \cdot(1 / \mu)$ & & $9 \Delta / \Delta(r \cdot / \cdot)$ & بيشتر از •9 سال & \\
\hline & $r / \Lambda(Y / V)$ & & $\wedge 9 / 9(r q / \Delta)$ & & $Y / \Delta(Y / I)$ & & $\Delta r / Y(\mid N / q)$ & كمتر از ..1 & \\
\hline & $1 / Y(\cdot / 9)$ & & $1 \cdot \Delta / \Gamma(r F / V)$ & & $r / \Delta(\cdot / V)$ & & $V \cdot / 9(\mid r / f)$ & $1 \cdot 1-Y .$. & \\
\hline
\end{tabular}




\begin{tabular}{|c|c|c|c|c|c|c|c|c|c|}
\hline \multirow[t]{3}{*}{$<\cdot / \cdots)$} & $1 / \cdot(\cdot / \Delta)$ & $<\cdot 1 \cdots 1$ & $94 / \cdot(r \cdot / 9)$ & $<\cdot 1 \cdot \cdots$ & $r / \cdot(\cdot / 9)$ & $<\cdot 1 \cdot \cdots 1$ & $V F / V(I I / Y)$ & $r \cdot l-r .$. & اندازه \\
\hline & $1 / \cdot(\cdot / \Delta)$ & & $V \Delta / 9(19 / 4)$ & & $F / \cdot(\cdot / \Lambda)$ & & $\wedge 1 / \Gamma(V / 9)$ & $f \cdot 1-9 .$. & \\
\hline & $\cdot / \Lambda(\cdot / f)$ & & $W / 9(1 r / 9)$ & & $r / q(\cdot / V)$ & & $\Lambda \mathrm{r} / \mathrm{V}(\mathrm{V} / \mathrm{F})$ & بالاتر از 1. & \\
\hline \multirow{4}{*}{$<\cdot 1 \cdot \cdot 1$} & $\Gamma / Y(r / V)$ & \multirow{4}{*}{$\cdot / 1 H V$} & $\Lambda r / q(\& \Delta / \Lambda)$ & \multirow{4}{*}{$<\cdot / \cdots)$} & $\Gamma / Y(r / 9)$ & \multirow{4}{*}{$<\cdot / \cdots)$} & $\Delta \Lambda / \cdot(Y Y / I)$ & كمتر از ب نفر & \multirow{4}{*}{ كار كنان } \\
\hline & $1 / 7(1 / 9)$ & & $q F / F(K F / 9)$ & & $Y / V(1 / \Delta)$ & & $4 \Delta / V(\mid \wedge / F)$ & r تأ نفر & \\
\hline & $1 / 9(1 / 9)$ & & $q F / Y(K V / \Lambda)$ & & $r / \mathcal{F}(\cdot / \Lambda)$ & & $\Delta ৭ / \Gamma(I V / \cdot)$ & Fا Fا نقر & \\
\hline & $\Gamma / \cdot(\Gamma / \mu)$ & & $q \Delta / r(F q / \cdot)$ & & $Y / Y(\cdot / 9)$ & & $01 / 9(1 / / 9)$ & و تا منفر & \\
\hline
\end{tabular}

مطالعات متعددى با استفاده از نمودار يابنلاسو به ارزشيابى

بيمارستانهاى استانهاى ايران يرداختند. به عنوان مثال، مطالعهاى در سال \&هب در || بيمارستان دانشگاه علوم يزشكى كردستان نشان داد كه فقط دو بيمارستان در ناحيه ب نمودار يابن لاسو قرار داشتند. سه بيمارستان در هر كدام از نواحى (r Y و F نمودار يابن لاسو قرار داشتند (N). در يثوهشى ديكر كه در اب بيمارستان وابسته به دانشكاه علوم يزشكى مشهد در سال سوسا انجام شد، 19 درصد بيمارستانها در ناحيه ب نمودار يابن لاسو قرار داشتند. به ترتيب، نمودار يابن لاسو قرار داشتند (19). در مطالعهاى كه در بيمارستان آموزشى دانشكاه علوم يزشكى شيراز در سال rوسا انجام شد، اب درصد بيمارستانها در ناحيه سوم نمودار يابن لاسو قرار داشتند (·r). اين مطالعات يراكنده استانى هم نشان مي دهند كه كارايى بيمارستانهاى كشور يايين است.

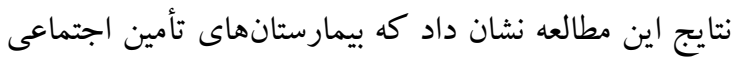
و خصوصى از كارايى بيشترى نسبت به ساير بيمارستانها

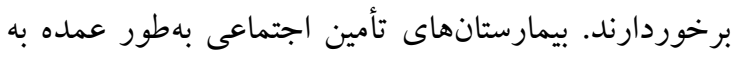

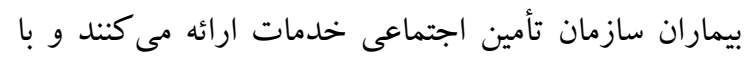

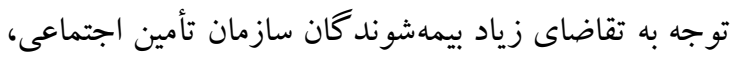

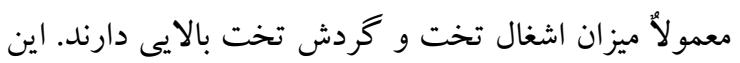

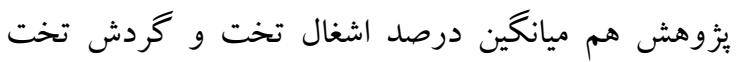

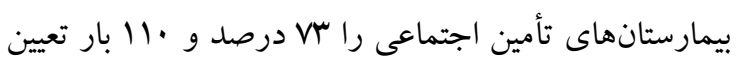

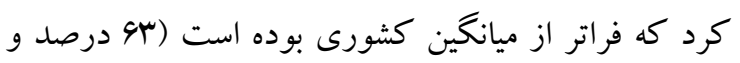

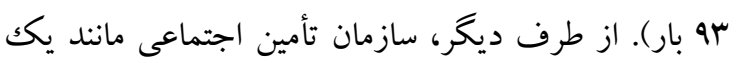
هولدينك عمل كرده و نقش حمايتى از بيمارستانهاى تابعه
اين مطالعه با هدف ارزشيابى كارايى بيمارستانهاى عمومى كشور و شناسايى عوامل موثر بر كارايى آنها انجام شد.

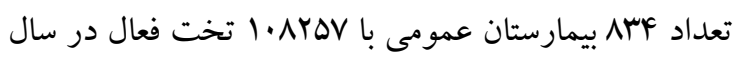

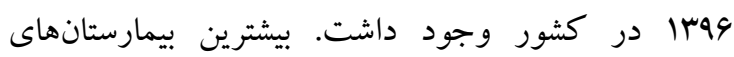
عمومى در استانهاى تهران، فارس و اصفهان و كمترين بيمارستانهاى عمومى در استانهاى قم، كهيكلويه و بوير احمد و جهارمحال و بختيارى قرار داشت. ميانگين اشغال تخت بيمارستانهاى عمومى كشور 9Y/A درصد، ميانكين

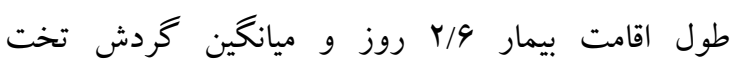
بيمارستانهاى عمومى كشور \&/ه بار بوده است. در اين يُزوهش از نمودار بابنلاسو براى ارزشيابى كارايى

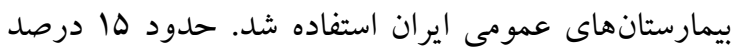
بيمارستانهاى عمومى ايران در ناحيه سوم نمودار يابن لاسو

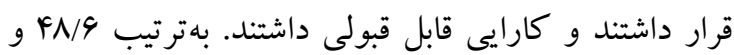

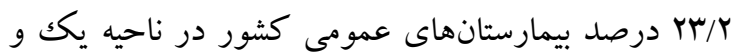

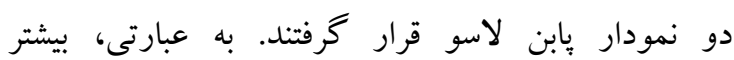
بيمارستانهاى عمومى كشور كارايى كمى دارند. بيمارستانهاى F استان جهارمحال و بختيارى، سيستان و بلوجستان، آذربايجان غربى و گلستان داراى عملكرد مطلوب بودند. بيمارستانهاى Yr استان كشور در ناحيه يك نمودار يابنلاسو قرار دارند و سطح كارايى آنها در حداقل ممكن است. كارايى بيمارستانهاى استانهاى كرمانشاه،

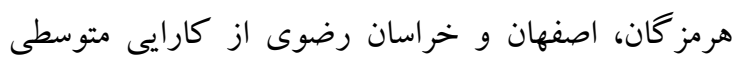
برخوردار هستند. اين يزوهش نشان داد كه بيمارستانهاى نواحى rا، r، أو ا به ترتيب كارايى بيشتر تا كمتر دارند. 
آلمان منجر به افزايش Y/9 تا F/9 درصدى كارايى آن شد (YN). بنابراين، مديران بيمارستانهاى دولتى بايد توجه بيشترى به ارتقاى كارايى و استفاده بهينه از منابع داشته باشند. بخش خصوصى از استراتزىها و فنون مديريتى و اقتصادى براى افزايش كارايى استفاده مى كنند. مديران بيمارستانهاى دولتى نيز مىتوانند از استراتزىهاى افزايش كارايى مورد استفاده در بخش خصوصى براى افزايش كارايى بيمارستانهاى خود استفاده كنند. نتايج اين مطالعه نشان داد كه بيمارستانهاى درمانى از كارايى بيشترى نسبت به بيمارستانهاى آموزشى، يزوهشى و درمانى برخوردارند. مطالعات قبلى هم نشان مىدهد كه بيمارستانهاى آموزشى از كارايى كمترى نسبت به به بـ بيمارستانهاى غير آموزشى برخوردار هستند (.r-1Y). بيمارستانهاى آموزشى وظايفى نظير آموزش و يثزوهش دارند كه هزينهبر بوده و ممكن است با اصل كارايى هماهنگك نباشد. از طرف ديخر، مشاركت دانشجويان علوم يزشكى در فرايند ارائه خدمت به بيماران، مىتواند منجر به اتلاف منابع بيمارستانى شود. مطالعاتى نشان دادند كه هزينه

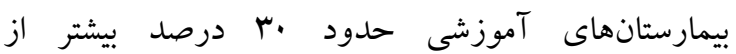
بيمارستانهاى غير آموزشى است (Yr-اM). بدون شك، استفاده از يزشكان و برستاران با تجربه در بيمارستانهاى درمانى منجر به افزايش كارايى آنها مىشود. بنابراين، مديران بيمارستانهاى آموزشى با بكارگيرى اقداماتى نظير آموزش دانشجويان علوم بزشكى در زمينه كارايى و ضرورت استفاده بهينه از منابع بيمارستانى، تدوين دستور العمل هاى مرتبط و نظارت و كنترل بيشتر مديران بخش هاى بيمارستانى بر عملكرد دانشجويان، مىتوانند مانع از اتلاف منابع محدود بيمارستان شوند. اندازه بيمارستان بر كارايى آن اثر مى گذارد. بيشترين ميزان كارايى در مطالعه حاضر در بيمارستانهاى بين 1. تخت مشاهده شد. بيمارستانهاى ناحيه ب نمودار پابن لاسو

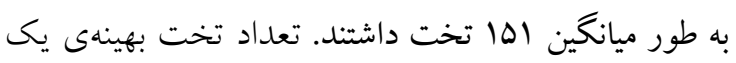

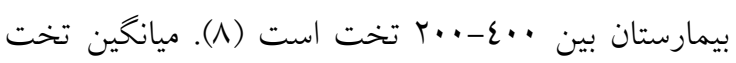

را دارد و با مشاركت در فرايندهاى برنامهريزى، آموزش، توانمندسازى، نظارت و ارزشيابى به كاهش هزينهاى بيمارستانهاى تابعه كمكك مى كند. در نتيجه، بيمارستانهاى وابسته به سازمان تأمين اجتماعى كارايى بيشترى نسبت به بيمارستانهاى مستقل خصوصى دارند. توسعه بيمارستانهاى زنجيرهاى خصوصى در اين راستا توصيه مىشود. يثزوهشهاى قبلى نتايج متفاوتى در زمينه رابطه بين نوع

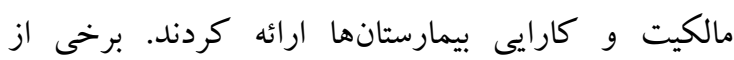
مطالعات، كارايى بيشتر بيمارستانهاى خصوصى را نسبت به بيمارستانهاى عمومى و دولتى تأييد كردند (YY-YI). در مقابل، برخى مطالعات نشان دادند كه بيمارستانهاى غير انتفاعى كار آمدتر از بيمارستانهاى انتفاعى خصوصى هستند

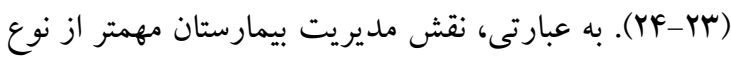
ماليكت بيمارستان است. بيمارستانهاى خصوصى معمولاً با هدف كسب سود و افزايش كارايى تأسيس مىشوند. در نتيجه، اندازه اين بيمارستانها نسبت به بيمارستانهاى دولتى كو جكتر بوده، تر كيب بهينهاى از منابع رابكار گرفته، اتلاف منابع را كاهش مىدهند، متوسط اقامت بيماران پايين و كردش تخت بالايى دارند. بنابراين، در صورت داشتن سيستم مديريت قوى، انتظار مىرود كه بيمارستانهاى دولتى هم از كارايى بيشترى برخوردار شوند. مدل سنتى سازمان بوروكراتيك ماكس وبر كه خدمات بايد توسط سازمانهاى دولتى ارائه شود و بروكراسى از طريق مديريت واحد و يكسانسازى فرايندهاى جارى منجر به صرفهجويى و كارايى مىشود، در دهه •191 ميلادى با شكست مواجه شد (YO). بخش دولتى ذاتاً از كارايى و وِاسخگويى كمترى نسبت به بخش خصوصى برخوردار است (YT). در نتيجه، حضور بخش خصوصى در ارائه خدمات سلامت در كشورهاى در حال توسعه در سالهاى اخير با توجه به كمبود منابع دولت و كارايى يايين بخش دولتى، افزايش داشته است (YV). مطالعهاى نشان داد كه خصوصى سازى يكك بيمارستان دولتى در 
مشاركت فعالى در كاهش هزينههاى غير ضرورى و افزايش كارايى داشته باشند. يزشكان نقش مهمى در ارائه خدمات

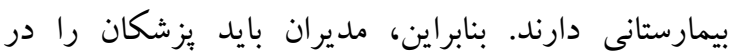
برنامه هاى مديريت كيفيت و كنترل هزينه مشار كت دهند. اين يزووهش همجنين، بين قدمت بيمارستانها و شاخصهاى

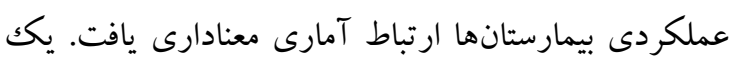

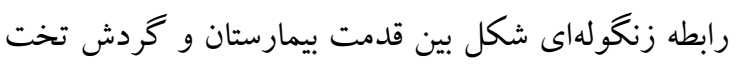
بيمارستان مشاهده شد. بيمارستانهاى با ال تال .ب سال

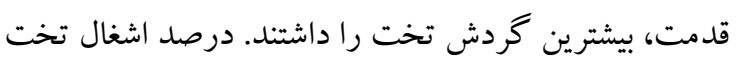

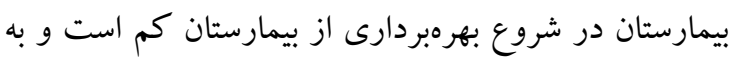
مرور زمان با شناخت بيشتر مردم نسبت به بيمارستان، افزايش

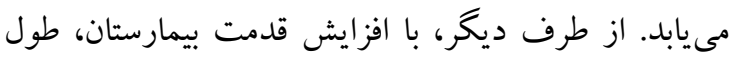

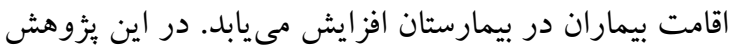

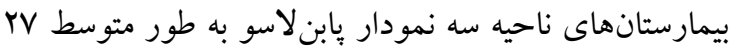
سال قدمت داشتند كه كمتر از متوسط قدمت بيمارستانهاى

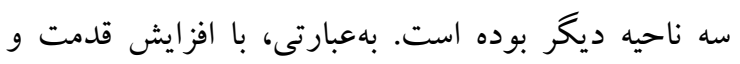

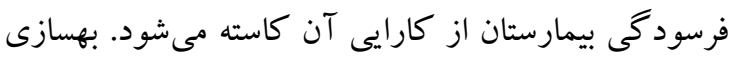
بيمارستان و ارتقاى تكنولوزى آن منجر به افزايش كارايى آن خواهد شد. بنابراين، اقدامات جدى براى بازسازى بيمارستانهاى قديمى كشور بايد به عمل آيد. مطالعات قبلى نشان دادند كه سازمانها در بازارهاى رقابتى لمانى از كارايى بيشترى برخوردار هستند (الr و צr). بيمارستانها در مناطق دور و روستايى از كارايى كمترى نسبت به به بـ بيمارستانهاى مناطق شهرى برخوردار هستند (rV). بنابر اين، مديران بيمارستانها در شهرهاى با تعداد بيمارستان بيشتر،

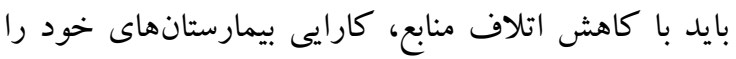

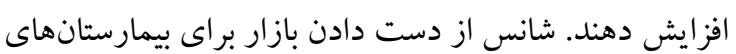
ناكارامد به ويزه به هنگام ركود اقتصادى در محيطهاى رقابتى بيشتر است. پِ از شناسايى ميزان كارايى بيمارستانهاى عمومى كشور بايد علل ناكارايى بيمارستانها شناسايى شوند. يكك مطالعه بئه

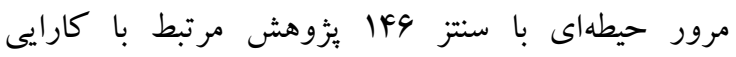

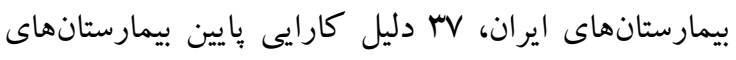

بيمارستانهاى كشور •rا تخت در سال 97\% بود. حدود 0./1 و M T/ درصد بيمارستانهاى كشور زير ..1 تخت

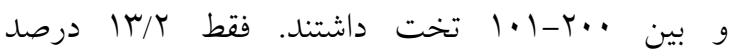

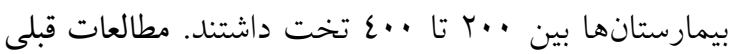

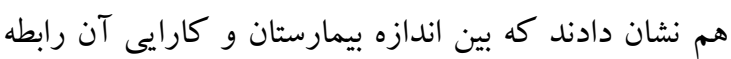

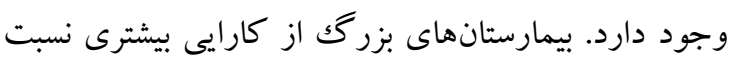

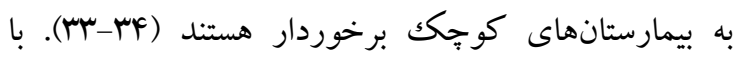
توجه به مقدار زياد هزينهاى ثابت بيمارستان نسبت به به بهان هزينهاى متغير، با افزايش تعداد تختها تا ميزانى، به دليل صرفهجويى ناشى از مقياس Economies of scale؛ كارايى بيمارستان افزايش مىيابد. در صورت افزايش تعداد تختهاى بيمارستانى از اين ميزان، متوسط هزينههاى بيمارستانى افزايش خواهد يافت. در اين حالت، ظرفيت بيمارستان بسيار بيشتر از حجم فعاليتهايش بوده و ناكار آمدى ظرفيتى Diseconomies of scale بهوجود بساد مى آيد. از آن طرف، بيمارستانهاى كوجگك با توجه به تعداد كم بيماران بسترى و بالا بودن هزينههاى ثابت از

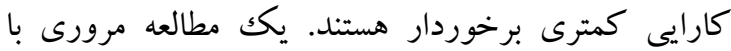

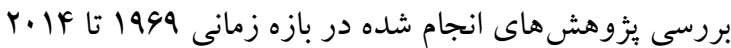
ميلادى نتيجه گرفت كه تعداد تخت بهينه براى كسب لتب

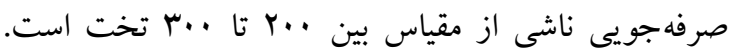

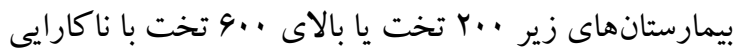

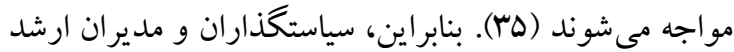
دانشگاههاى علوم يز شكى در طرح حهاى توسعهاى خود اندازه مطلوب بيمارستانها را مورد توجه قرار دهند. به عنوان مثال، توسعه بيمارستانهاى كوجّك و افزايش تختهاى آنها به جاى احداث يكك بيمارستان كو جكك ديخر در همان منطقه

$$
\text { ييشنهاد مى شود. }
$$

در اين يُزوهش، بيشتر بيمارستانهاى ناحيه سه نمودار

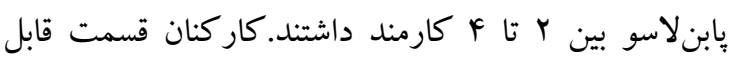
توجهى از هزينه بيمارستانها را تشكيل مىدهند. تعداد كار كنان بيمارستان بايد متناسب با حجم بيماران تعديل شود.

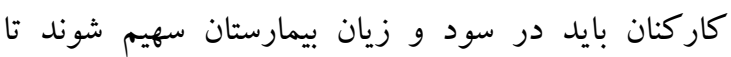


بيشترين ارزش را در تأمين، ارتقاء و حفظ سلامتى مردم

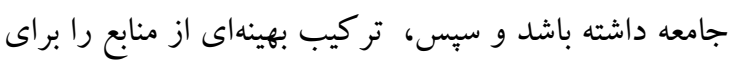

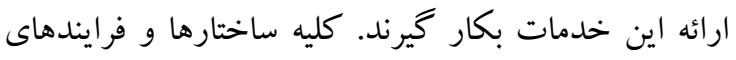
بيمارستانى بايد مورد بررسى قرار گيرد و فعاليتهاى فاقد ارزش، حذف شوند. افزايش كارايى بيمارستانها از طريق

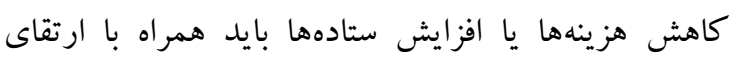
كيفيت خدمات بيمارستانى باشد تا نتايج بايدارترى به همراه

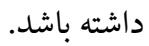
عملكرد مديران بر كارايى بيمارستانها تأثير زيادى دارد (F)-F•) مديريت خدمات بهداشتى و درمانى يا مديريت بيمارستان) بايد براى مديريت ارشد بيمارستانها استفاده شود تا با

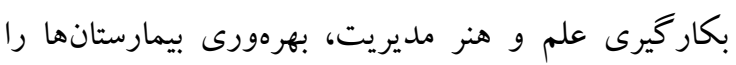
افزايش دهند. مديران حرفهاى بيمارستانها از طريق اقداماتى نظير تدوين شرح وظايف و شرايط احراز درست براى مشاغل بيمارستانى، تشويق كار تيمى، استفاده از تركيب

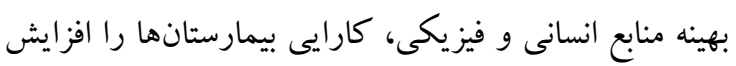

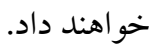

\section{نتيجه كيرى}

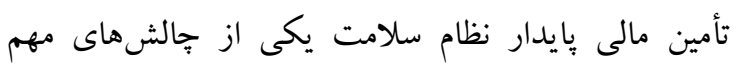

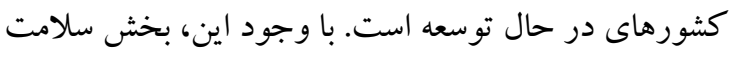

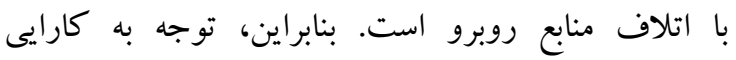

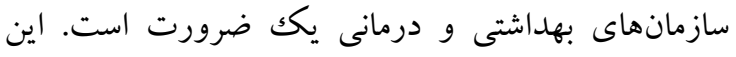

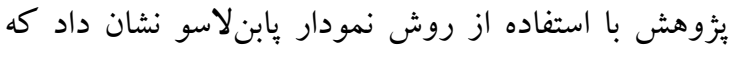

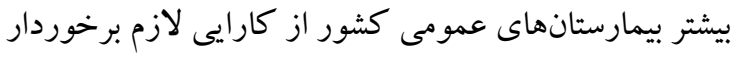

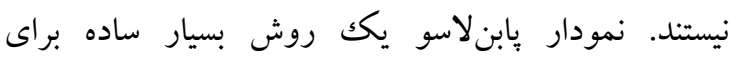

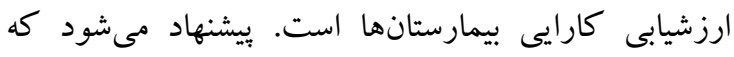

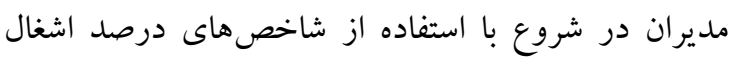
تخت و كردش تخت بيمارستانها، ارزيابى اوليهاى از

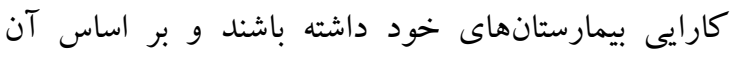

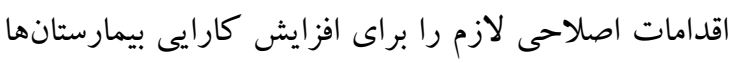

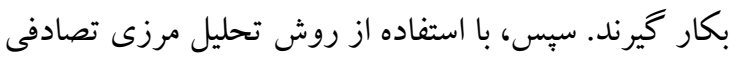

كشور را شناسايى و در جهار سطح متا (وزارت بهداشت)،

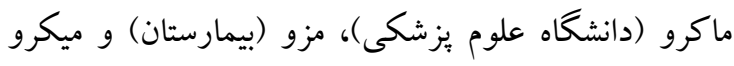

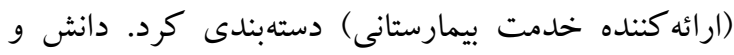

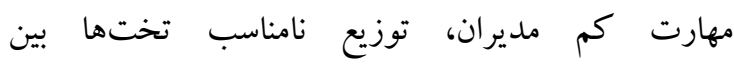

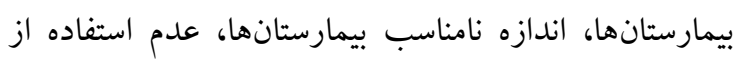

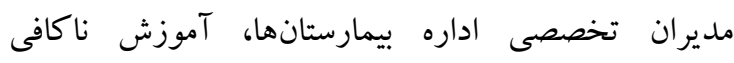

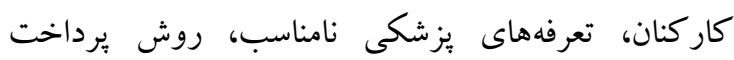

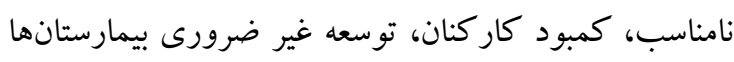

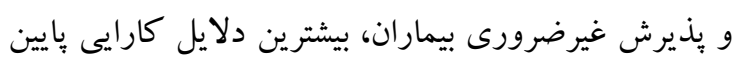
بيمارستانهاى ايران بودند (11) در نهايت، پِ از شناسايى علل ناكارايى بيمارستانها بايد

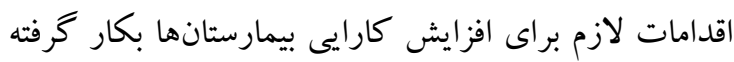

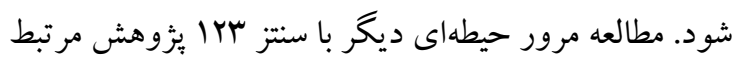

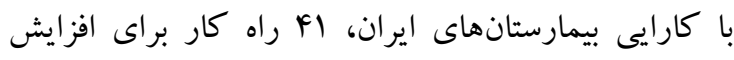

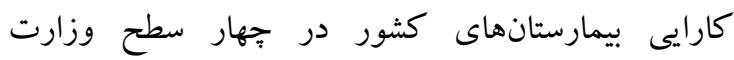
بهداشت، دانشگاه علوم بزشكى، بيمارستان و ارائه كنند كان خدمات بيمارستانى شناسايى كرد. اجراى مديريت كيفيت،

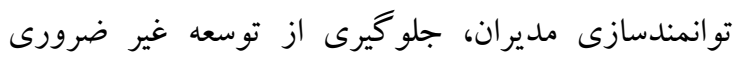
بيمارستانها، تخصيص تختهاى بيمارستانى متناسب با نياز

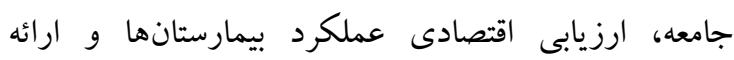
بازخورد به مدير ان، توزيع صحيح تخت ها بين بيمارستانها و ورئا

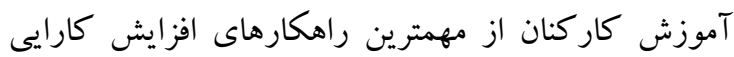

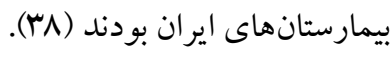
بيمارستانها درصد قابل توجهى از هزينهاى بخدش بردس سلامت

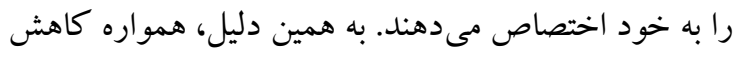

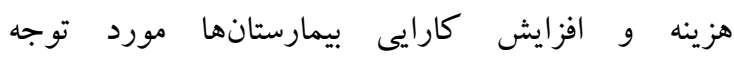

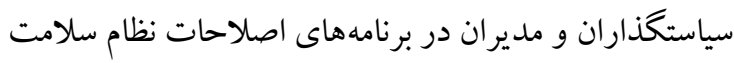

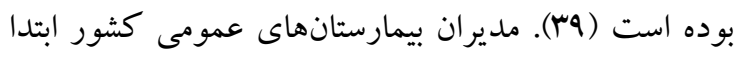

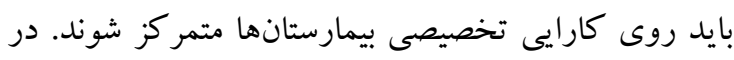

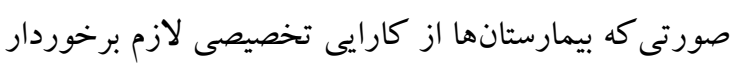

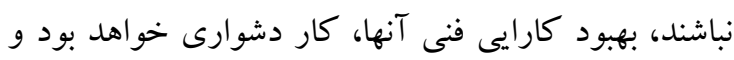

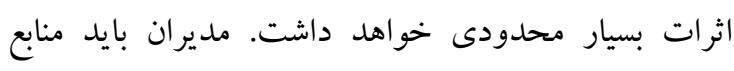

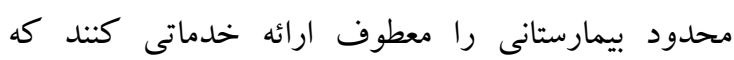




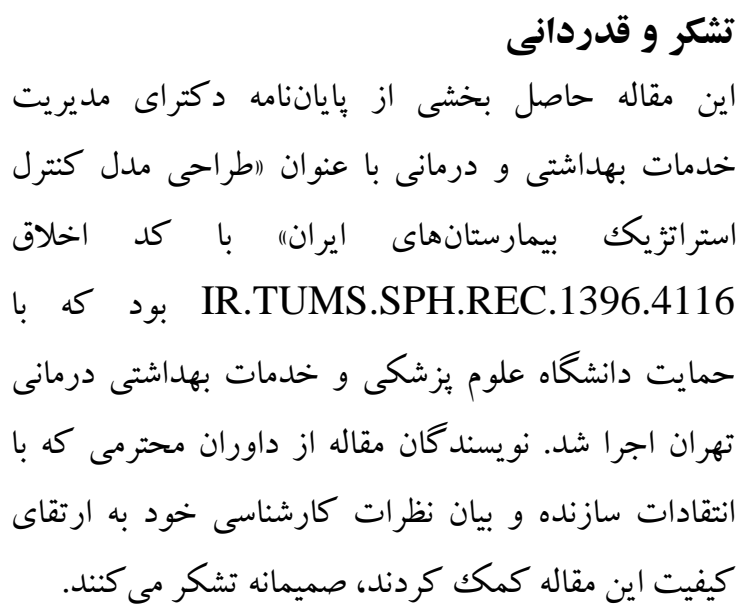

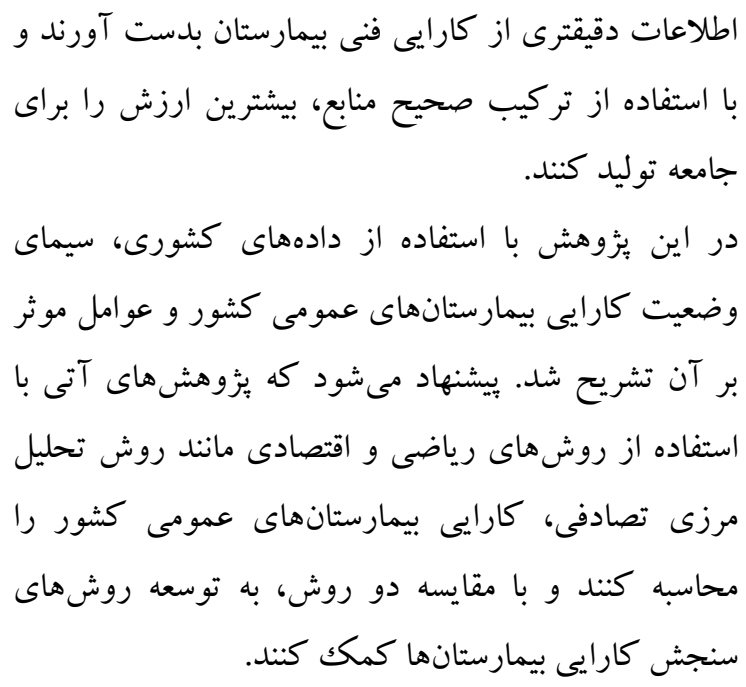

منابع

1. World Health Organization. Global spending on health: a world in transition. World Health Organization; 2019.

2. World Health Organization. World health statistics 2019: Monitoring health for the SDGs sustainable development goals. World Health Organization; 2019.

3. OECD Health expenditure and financing. Available from: https: //stats.oecd.org/Index.aspx?DataSetCode=SHA (Accessed 12 August 2020).

4. Mosadeghrad AM. Hospital accreditation: The good, the bad, and the ugly, Int J Healthc Manag. 2020:1-5.

5. World Health Organization. The world health report: health systems financing: the path to universal coverage. Geneva: World Health Organization; 2010.

6. Berwick DM, Hackbarth AD. Eliminating waste in US health care. JAMA. 2012; 07(14): 1513-1516.

7. WHO. WHO global health expenditure atlas. Geneva: World Health Organization; 2014.

8. Mosadeghrad AM, Esfahani P, Nikafshar M. Hospitals' efficiency in Iran: A systematic review and meta-analysis of two decades of research. Journal of Payavard Salamat. 2017;11(3):318-31.

9. Nayar P, Ozcan YA. Data envelopment analysis comparison of hospital efficiency and quality. J Med Syst. 2008;32(3):193-9.

10. Huerta TR, Harle CA, Ford EW, Diana ML, \& Menachemi N. Measuring patient satisfaction's relationship to hospital cost efficiency: Can administrators make a difference? Health Care Manage Rev. 2016; 41(1):56-63.

11. Mosadeghrad AM, Esfahani P, Afshari M. Reasons for low efficiency in Iranian hospitals: A scoping review of two decades of research. Ebnesina. 2020; 22 (1):29-46. [in Persian] 12. Pabon Lasso H. Evaluating hospital performance through simultaneous application of several indicators. Bulletin of the Pan American Health Organization, 1986; 20 (4): 341-357.

13. Charnes A, Cooper WW, Rhodes E. Measuring the efficiency of decision making units. Eur. J. Oper. Res. 1978;2(6):429-44.

14. O’Neill, L., Rauner, M., Heidenberger, K., \& Kraus, M. (2008). A cross-national comparison and taxonomy of DEA-based hospital efficiency studies. Socio-Economic Planning Sciences, 42(3), 158-189. 
15. Aigner D, Lovell $\mathrm{C} \&$ Schmidt $\mathrm{P}$. Formulation and estimation of stochastic frontier production function models. J Econom. 1977; 6(1): 21-37.

16. Katharakisa G, Katharaki M, Katostaras T. SFA vs. DEA for measuring healthcare efficiency: A systematic review. Int. J. Stats. Med. Res., 2013; 2 (2): 152-166.

17. Mosadeghrad A M, Janbabaei G, Kalantari B, Darrudi A, Dehnavi H. Equity in distribution of hospital beds in Iran. Sci. J. Kurdistan Univ. Medical Sci. 2020; 24 (6) :12-36.

18. Moradi G, Piroozi B, Safari H, Nasab NE, Bolbanabad AM, Yari A. Assessment of the efficiency of hospitals before and after the implementation of health sector evolution plan in Iran based on Pabon Lasso model. Iran. J. Public Health. 2017;46(3):389.

19. Kalhor L, Kalhor R, Darzi Ramandi F, Rafiei S, Tabatabaee SS, Azmal M. Performance Analysis of Hospitals Affiliated to Mashhad University of Medical Sciences Using the Pabon Lasso Model: A Six-Year-Trend Study. Biotech Health Sci. 2016; 3(4):e38629

20. Bastani P, Lotfi F, Moradi M, Ahmadzadeh MS. The performance analysis of teaching hospitals affiliated with shiraz university of medical sciences before and after health system reform plan using pabon lasso model. J Rafsanjan Univ Med Sci. 2016;15(8):781-92.

21. Leleu H, Al-Amin M, Rosko M, Valdmanis VG. A robust analysis of hospital efficiency and factors affecting variability. Health Serv Manage Res. 2018;31(1):33-42.

22. Guerrini A, Romano G, Campedelli B, Moggi S, Leardini C. Public vs. private in hospital efficiency: Exploring determinants in a competitive environment. Int $\mathbf{J}$ Publ Admin. 2018;41(3):181-9.

23. Jehu-Appiah C, Sekidde S, Adjuik M, Akazili J, Almeida SD, Nyonator F, Baltussen R, Asbu EZ, Kirigia JM. Ownership and technical efficiency of hospitals: evidence from Ghana using data envelopment analysis. Cost Eff. Resour. Alloc. 2014;12(1):9.

24. McKay NL, Deily ME, Dorner FH. Ownership and changes in hospital inefficiency, 19861991. Inquiry. 2002; 39(4): 388-399.

25. Du Gay P. In praise of bureaucracy: Weber-organization-ethics. London: Sage; 2000.

26. Ouchi WG. Markets, bureaucracies, and clans. Adm Sci Q, 1980; 25 (1):129-41.

27. Lim MK. Transforming Singapore health care: public-private partnership. Ann. Acad. Med. Singap., 2005; 34(7), 461-467.

28. Tiemann O, Schreyögg J. Changes in hospital efficiency after privatization. Health Care Manag Sci. 2012;15(4):310-326.

29. Grosskopf S, Margaritis D, Valdmanis V. Comparing teaching and non-teaching hospitals: a frontier approach (teaching vs. nonteaching hospitals). Health Care Manag Sci. 2001; 4(2): 83-90.

30. Rosko M, Wong HS, Mutter R. Characteristics of high-and low-efficiency hospitals. Med Care Res Rev. 2018;75(4):454-78.

31. Cameron JM. The indirect costs of graduate medical education. N. Engl. J. Med. 1985;312(19):1233-8.

32. Rich EC, Gifford G, Luxenberg M, Dowd B. The relationship of house staff experience to the cost and quality of inpatient care. JAMA. 1990;263(7):953-7.

33. Asbu EZ, Masri MD, Al Naboulsi M. Determinants of hospital efficiency: A literature review. Int J Health Care, 2020; 6 (2): 44-53

34. Groff JE, Lien D, Su J. Measuring efficiency gains from hospital mergers. Research in Healthcare Financial Management. 2007;11(1):77.

35. Giancotti M, Guglielmo A, Mauro M. Efficiency and optimal size of hospitals: results of a systematic search. PLoS ONE. 2017; 12(3): e0174533. 
36. Lee KH, Park J, Lim S, et al. Has competition increased hospital technical efficiency? Health Care Manag. 2015; 34: 106-112.

37. Yildiz MS, Heboyan V, Khan MM. Estimating technical efficiency of Turkish hospitals: implications for hospital reform initiatives. BMC Health Serv Res. 2018; 18(1): 401.

38. Mosadeghrad AM, Esfahani P, Afshari M. Strategies to improve hospital efficiency in Iran: A scoping review. Payesh. 2019; 18 (1):7-21.

39. Yousefinezhadi T, Mosadeghrad AM, Arab M, Ramezani M, Akbari-sari A. An analysis of hospital accreditation policy in Iran. Iran. J. Public Health. 2017. 46(10):1347-1358.

40. Besstremyannaya G. Managerial performance and cost efficiency of Japanese local public hospitals: A latent class stochastic frontier model. Health Econ. 2011; 20 (Suppl 1): 19-34.

41. Mosadeghrad AM, Ferlie E. Total quality management in healthcare. Management innovations for healthcare organizations: adopt, abandon or adapt. York: Routledge; 2016:378-96. 